INTERNATIONAL MONETARY FUND

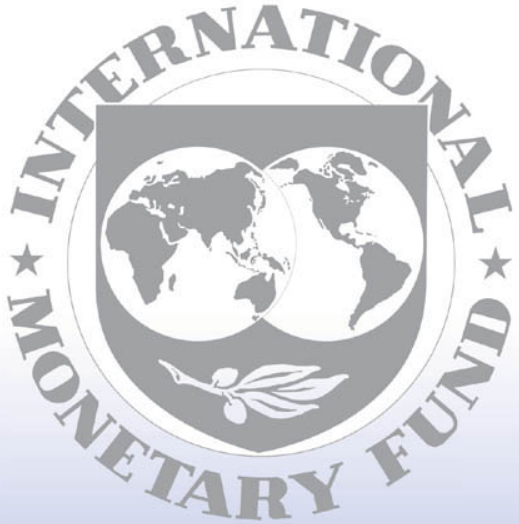

Staff

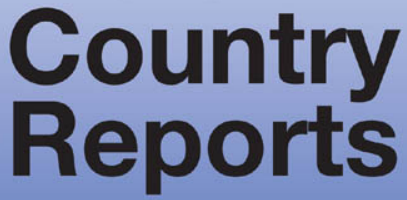




\section{Chad: Selected Issues}

This Selected Issues paper for Chad was prepared by a staff team of the International Monetary Fund as background documentation for the periodic consultation with the member country. It is based on the information available at the time it was completed on January 16, 2009 The views expressed in this document are those of the staff team and do not necessarily reflect the views of the government of Chad or the Executive Board of the IMF.

The policy of publication of staff reports and other documents by the IMF allows for the deletion of market-sensitive information.

\footnotetext{
Copies of this report are available to the public from

International Monetary Fund $\bullet$ Publication Services

700 19th Street, N.W. • Washington, D.C. 20431

Telephone: (202) 623-7430 • Telefax: (202) 623-7201

E-mail: publications@imf.org • Internet: http://www.imf.org
}

\section{International Monetary Fund \\ Washington, D.C.}


This page intentionally left blank 
INTERNATIONAL MONETARY FUND

CHAD

\section{Selected Issues}

Prepared by Oscar Melhado (AFR), Anton Op de Beke (SPR); Alejandro Simone (FAD)

Approved by the African Department

January 16, 2009

Chapter I

Contents

Page

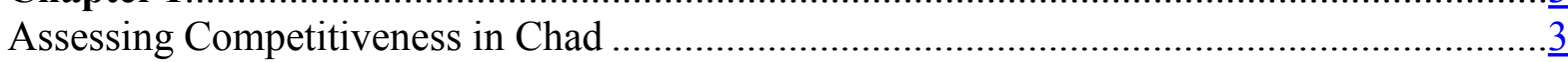

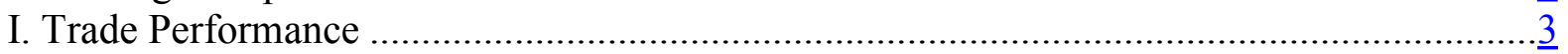

II. Balance of Payments Analysis and Vulnerabilities.........................................................

III. Dutch Disease in Chad ...............................................................................................

IV. Chad's Real Effective Exchange Rate …………….................................................

A. The Equilibrium Real Exchange Rate Approach ……………...................................

B. The Macroeconomic Balance Approach ..............................................................11

C. External Sustainability Approach.........................................................................13

V. Non-Exchange Rate Indicators of Competitiveness ......................................................

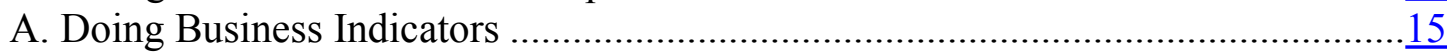

VI. Barriers to Internal and External Trade ………….....................................................

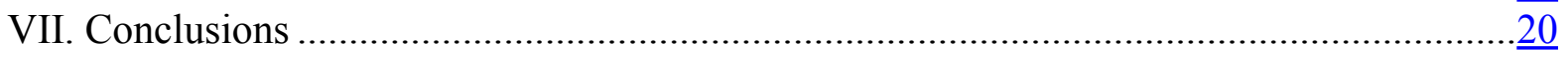

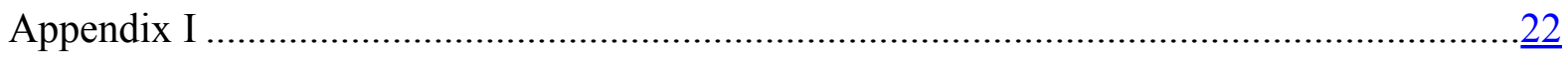

Figures

1. External Trade Performance, (1994-2007) ..........................................................................

2. Price of Key Non Tradables (index, base 1994) ..............................................................

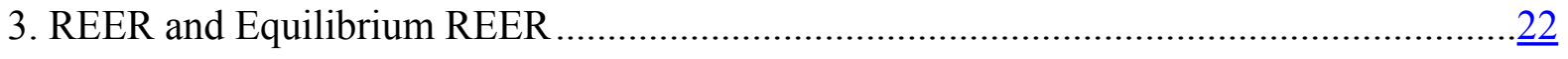

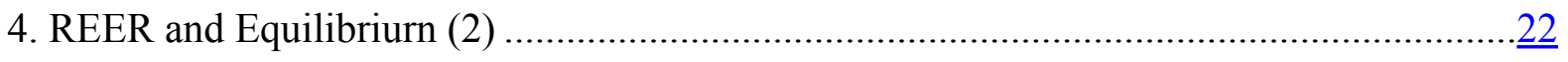

Tables

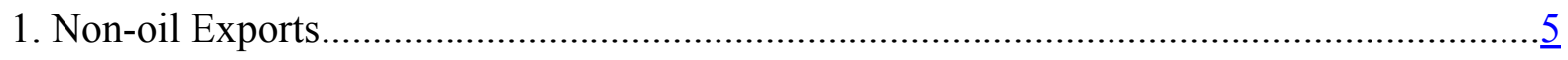

2. Oil Sector in Balance of Payments ...........................................................................

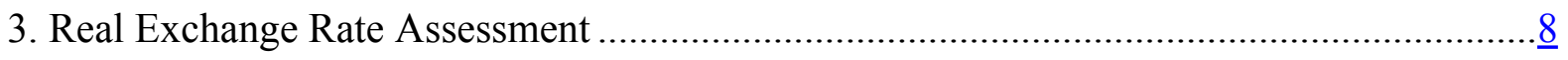

4. ARDL on Base Specification with Different Number of Lags ..........................................10

5. CEMAC Estimation .................................................................................................

6. Savings-Investment-Current Account Norm …………................................................ 


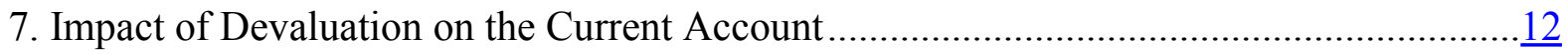

8. Results of the Macroeconomic Balance Approach........................................................

9. Net Foreign Assets Target (in percent of GDP).............................................................

10. Macroeconomic Balance Results (percent of GDP,

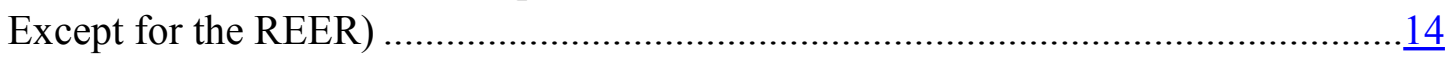

11. Relative Performance on Governance Indicators ……..................................................

12, Ranking on Doing Business Within Sub-Saharan Africa ..............................................

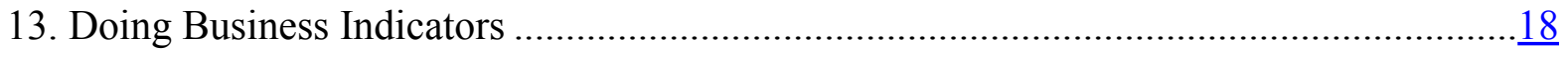

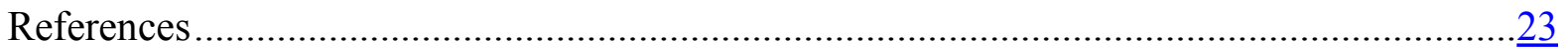

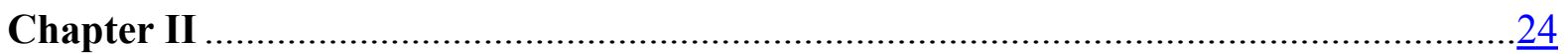

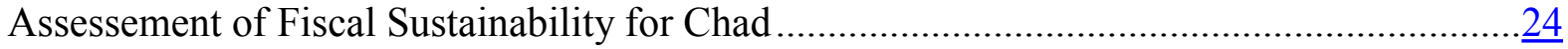

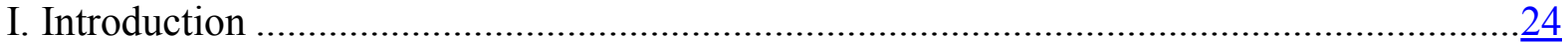

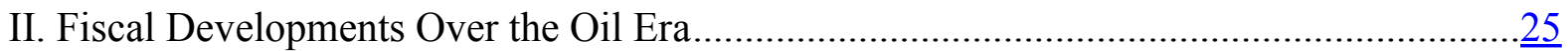

III. Assessing Sustainability and the Sustainable Non-Oil Primary Balance ……………........

IV. Reforms to Restore Fiscal Sustainability in Chad ..........................................................

Figures

1. Evolution of Selected Fiscal Aggregates; 2003-2008 (Proj.) ……........................................

2. Evolution of Main Components of Primary

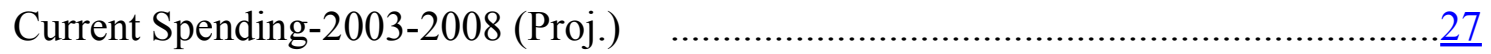

3. Evolution of the Overall Balance; 2003-2008 (Proj.) ......................................................28

4. Utilization of Oil Revenue by Oil Producing Countries 2000-2006...................................29

5. Oil Revenue, Annuity, and Asset Accumulation

(Constant Government Consumption Annuity as a Share of non Oil GDP.......................33

Tables

1. Main Macroeconomic, Oil Sector, and Habit Persistence

Parameter Assumptions ……………………………..............................................

2. Average Levels of Non-Oil Primary Deficit Under Different Approaches..........................

3. Sensitivity Analysis on NOPD Estimates ......................................................................

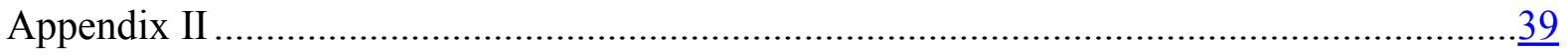

Appendix II Tables

1. Average Level of NOPD Under Additional PIH Approach Rules .......................................

2. Sensitivity Analysis of NOPD Estimates for Additional PIH Approach Rules.....................39

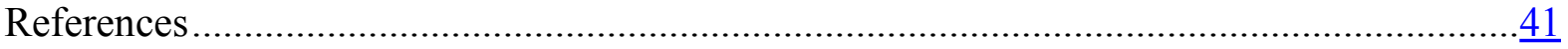




\section{CHAPTER I}

\section{Assessing Competitiveness In CHAD ${ }^{1}$}

1. This paper analyzes competitiveness in Chad since the advent of the oil era in the 2000s. Oil has since positioned itself as the key sector of a traditional economy that previously depended on agriculture and some light manufacturing. Oil is changing many features of an economy in which some part of the population is nomad and which has been in a state of war for over the last 30 years. The question here is whether Chad's competitiveness has been affected by oil production. Answering it is not easy for a number of reasons. First, the unstable security situation distorts the economic variables, and security risks may not be properly reflected in the data. Second, the quality of data, particularly on the external sector, is poor. Third, other than in the traditional sectors Chad does not have a solid production base against which to compare the impact of the oil economy.

2. The paper first describes Chad's trade performance and analyzes its balance of payment vulnerabilities. It then presents an econometric evaluation of the competitiveness of Chad's exchange rate. The quantitative assessment is supplemented by an analysis of indicators that capture Chad's competitiveness more directly, especially the fragile security situation and the poor quality of governance. Barriers to internal and external trade are identified in the last section.

\section{Trade Performance}

3. Over the past decade Chad's external trade relations have been fundamentally altered. The coming on stream of oil production in 2003 was preceded by construction of the ChadCameroon oil pipeline and the development of the Doba oil fields in southwestern Chad close to the Cameroon border. Doba reserves are estimated at about one billion proved barrels and are projected to be substantially depleted by 2025 , and none of the companies actively exploring has so far announced evidence of new profitable reserves. Total exports and imports over the past decade reflect pipeline construction and oil field development between 1999 and 2004 and the start of oil exports in 2004s. Because Chad is a price taker in the world oil market, and its production is determined by supply constraints, its competitiveness should be analyzed based on its non-oil exports and imports (Figure 1).

4. Chad's non-oil exports over the past decade have been flat. After the large devaluation of the CFA franc in 1994, export volumes rose for a few years but then fell back (see Table 1). In terms of GDP non-oil exports ended in 2008 at about the level of 1994 as

\footnotetext{
${ }^{1}$ Prepared by Oscar Melhado and Anton Op de Beke.
} 
Figure 1. Chad: External Trade Performance, (1994-2007)
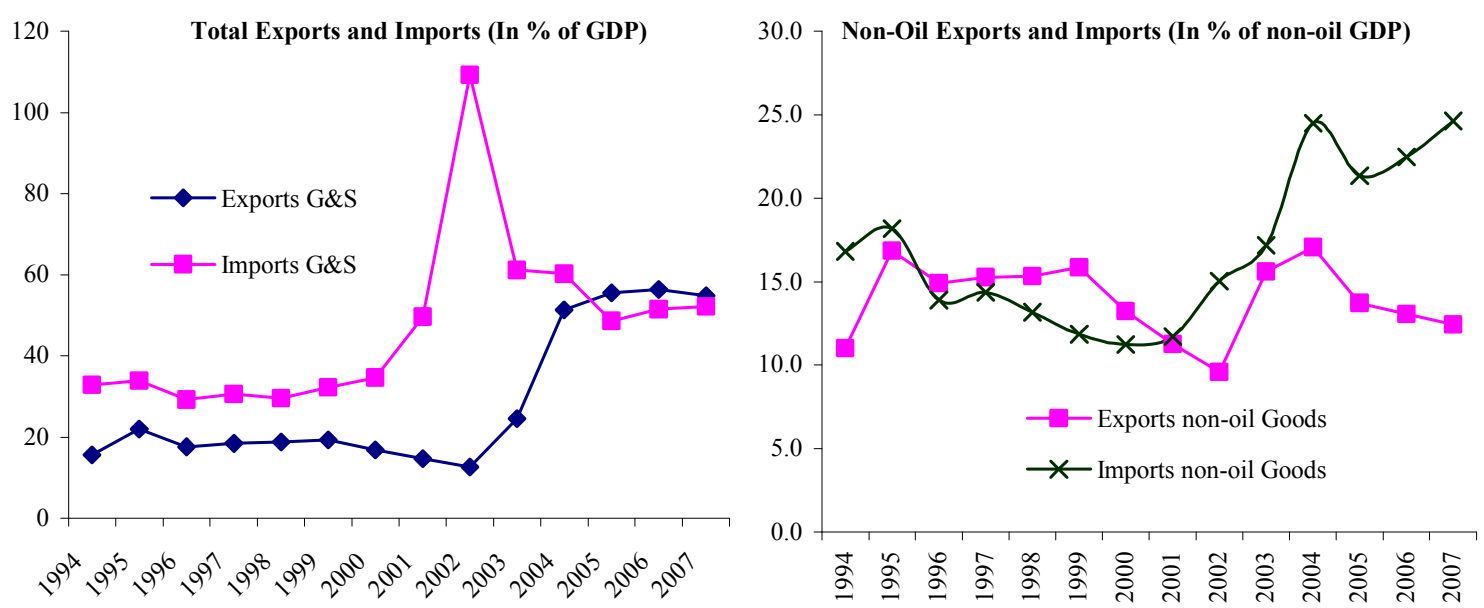

Non-Oil Current Account Balance (in \%

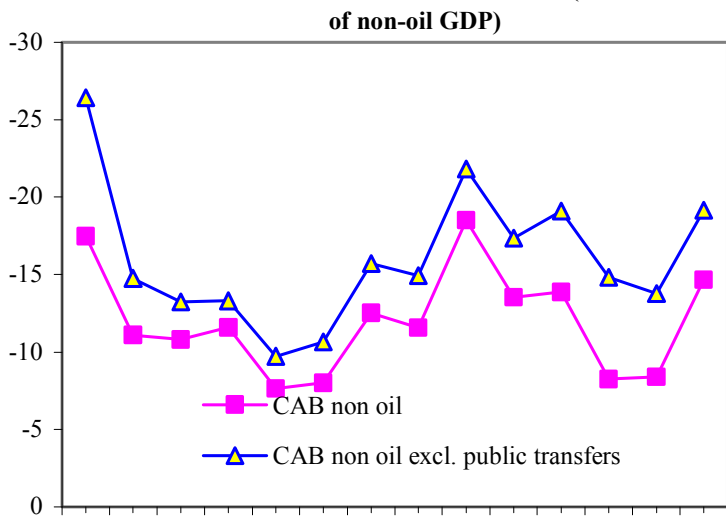

Export and Import Volumes (Index 1995=100)

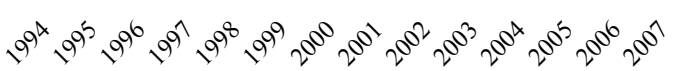
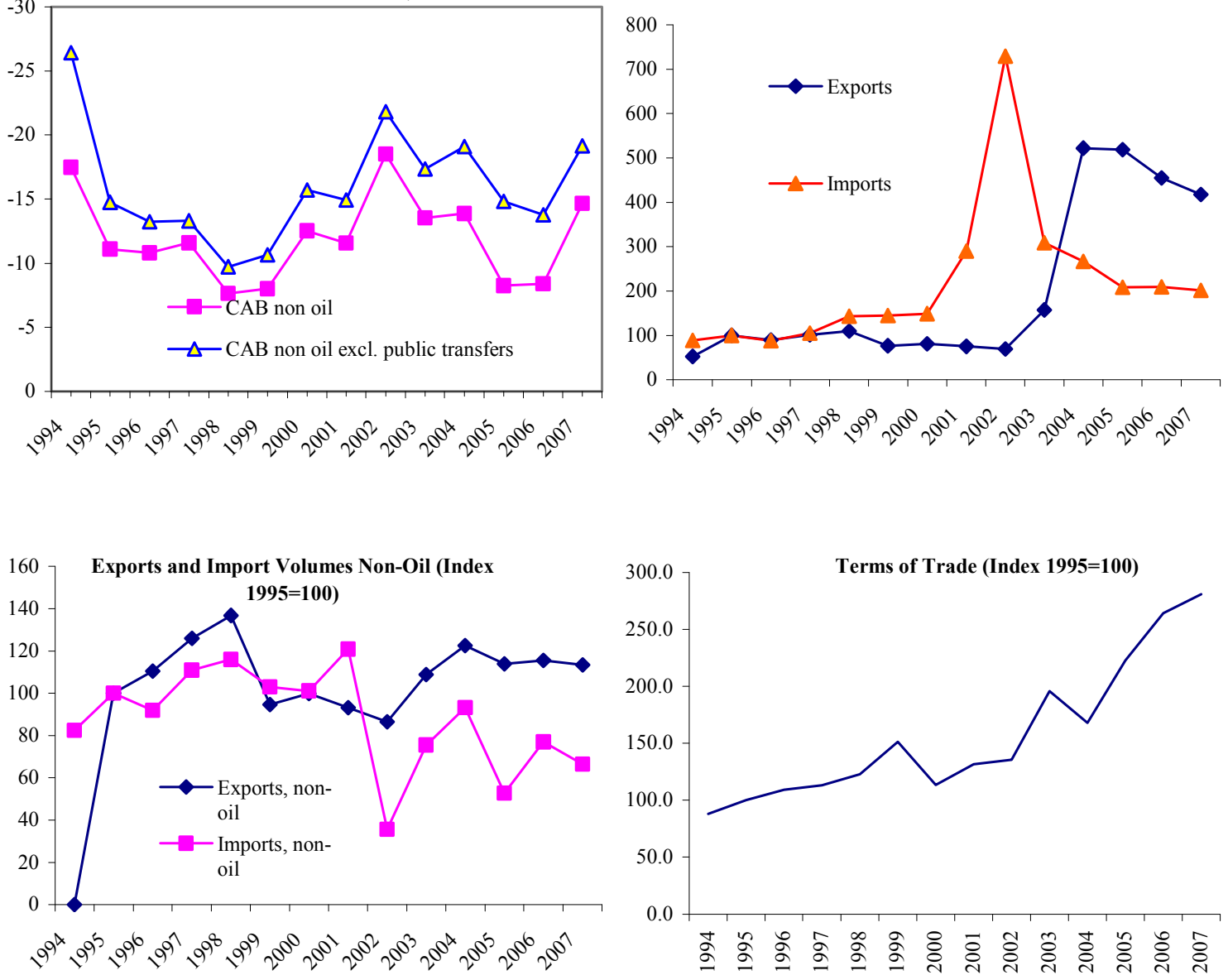

Source: Chadian authorities. 


\begin{tabular}{|c|c|c|c|c|c|c|c|c|c|c|c|c|c|c|c|}
\hline & 1994 & 1995 & 1996 & 1997 & 1998 & 1999 & 2000 & 2001 & 2002 & 2003 & 2004 & 2005 & 2006 & 2007 & 2008 \\
\hline & \multicolumn{15}{|c|}{ (in billions of CFA) } \\
\hline Livestock & 75 & 110 & 142 & 144 & 159 & 234 & 165 & 169 & 173 & 240 & 251 & 269 & 267 & 264 & 272 \\
\hline Cotton & 23 & 64 & 47 & 63 & 78 & 60 & 51 & 57 & 39 & 45 & 45 & 42 & 44 & 36 & 41 \\
\hline Arabic gum & 3 & 5 & 6 & 4 & 5 & 4 & 6 & 6 & 6 & 7 & 7 & 16 & 14 & 15 & 15 \\
\hline Other & 28 & 28 & 22 & 30 & 23 & 19 & 25 & 26 & 24 & 26 & 37 & 50 & 51 & 56 & 63 \\
\hline \multirow[t]{2}{*}{ Total } & 129 & 206 & 217 & 240 & 264 & 316 & 247 & 258 & 243 & 318 & 341 & 378 & 376 & 371 & 391 \\
\hline & \multicolumn{15}{|c|}{ (in percent of total) } \\
\hline Livestock & 58 & 53 & 65 & 60 & 60 & 74 & 67 & 66 & 71 & 75 & 74 & 71 & 71 & 71 & 70 \\
\hline Cotton & 18 & 31 & 22 & 26 & 29 & 19 & 21 & 22 & 16 & 14 & 13 & 11 & 12 & 10 & 10 \\
\hline Arabic gum & 3 & 2 & 3 & 1 & 2 & 1 & 2 & 2 & 3 & 2 & 2 & 4 & 4 & 4 & 4 \\
\hline Other & 21 & 14 & 10 & 12 & 9 & 6 & 10 & 10 & 10 & 8 & 11 & 13 & 14 & 15 & 16 \\
\hline \multirow[t]{2}{*}{ Total } & 100 & 100 & 100 & 100 & 100 & 100 & 100 & 100 & 100 & 100 & 100 & 100 & 100 & 100 & 100 \\
\hline & \multicolumn{15}{|c|}{ (in percent of non-oil GDP) } \\
\hline Livestock & 11 & 15 & 17 & 16 & 15 & 25 & 17 & 14 & 13 & 18 & 18 & 16 & 15 & 14 & 13 \\
\hline Cotton & 4 & 9 & 6 & 7 & 8 & 6 & 5 & 5 & 3 & 3 & 3 & 3 & 3 & 2 & 2 \\
\hline Arabic gum & 1 & 1 & 1 & 0 & 0 & 0 & 1 & 0 & 0 & 0 & 1 & 1 & 1 & 1 & 1 \\
\hline Other & 4 & 4 & 3 & 3 & 2 & 2 & 3 & 2 & 2 & 2 & 3 & 3 & 3 & 3 & 3 \\
\hline Total & 20 & 29 & 27 & 27 & 26 & 34 & 25 & 21 & 18 & 23 & 24 & 23 & 21 & 20 & 19 \\
\hline \multicolumn{16}{|l|}{ Memorandum item: } \\
\hline Non-oil exports/world imports & 100 & 149 & 145 & 135 & 149 & 164 & 99 & 103 & 98 & 133 & 130 & 127 & 111 & 104 & 100 \\
\hline
\end{tabular}

well the share of non-oil exports in world imports. Chad's main non-oil export products are livestock and cotton. The relative importance of cotton is decreasing while gum Arabic-a traditional product for Chad and Sudan-is gaining importance. "Other" exports are mostly agricultural, such as corn, sorghum, and peanuts.

5. The overall openness of the economy remained roughly the same, with exports and imports of non-oil goods each equaling 15 percent of GDP, until oil revenues in 2004 boosted non-oil imports. Since oil production began in 2003, Chad's terms of trade are dominated by international oil price movements, which through 2008 were extremely favorable. Chad's trade performance, while not signaling any trend in competitiveness, clearly indicates that Chad has not been able to take advantage of the opportunities offered to increase its share in world trade and diversify the economy beyond oil. Diversifying the economy will become more pressing as oil resources are depleted but is already necessary while oil resources are still abundant to help mitigate the deleterious effects of oil sector volatility.

\section{Balance of Payments Analysis and Vulnerabilities}

6. Chad's balance of payments is much affected by flows originating in the oil sector. The sector currently consists of a consortium of three international companies-Esso, Chevron, and Petronas - which produce 125,000 barrels of oil a day from six fields in the Doba region. Because Chad has no refinery, all oil produced is exported as crude through the Chad-Cameroon pipeline to the port city of Kribi. In an aggregate presentation of balance of payments factors, the size and volatility of the oil-related flows swamp the other flows. Moreover, oil sector vulnerabilities are quite distinct from other vulnerabilities. Therefore, although Chad does not prepare balance of payments reports separately for the oil and 
non-oil sectors, as do neighboring oil producers, it is useful to analyze the balance of payments based on consideration of estimates of oil-sector-related flows (see Table 2). ${ }^{2}$

7. Starting in 2000, foreign direct investment (FDI) in development of the Doba fields and construction of the pipeline dominated the capital and financial account. This generated substantial imports of oil-sector-related goods and even more so of services. When production began in 2003, the income account started showing sizable outflows representing the earnings of the oil companies, much of which re-enters the balance of payments as FDI. Oil exports peaked almost immediately, in 2004, and by 2008 had dropped about one quarter due to unforeseen problems with the geology of the field. Large investments in 2006-08 went to stabilize production levels, and further substantial investments will be required regularly simply to maintain production levels.

8. Because oil now accounts for 90 percent of exports, the trade account is obviously very sensitive to its price fluctuations, but the related vulnerability of the balance of payments is limited. First, production from the Doba field is profitable even at a Brent oil price of only \$20-\$25 per barrel. Second, the impact of a drop in oil prices is offset by reduced factor income outflows. Third, the substantial imports of goods and services necessary to maintain production are financed by the oil companies from retained earnings, supplemented if needed by internal financing. Thus, Chad's reserves are largely insulated from the direct effects of oil export shocks. However, the balance of payments is vulnerable to the possibility that fiscal policy would not react appropriately to adverse oil export shocks and the attendant reduction in revenue. If non-oil imports do not adjust in a timely manner, reserves could be depleted.

\section{Dutch Disease IN ChAD}

9. Dutch disease can emerge in an economy that benefits suddenly from increased revenues from rents, such as from mineral resources, or other external sources, such as foreign aid. To the extent that the increased aggregate demand is not fully directed to more imports, it bids up the price of nontradables in relation to tradables, which can be imported. This promotes a switch of production from tradables to nontradables, harming the export sector.

10. The effects of Dutch disease in Chad are hard to evaluate not only because data are lacking but also because the non-oil sector is underdeveloped. Before oil, the most important economic sector was agriculture, with cotton and cattle as the main exports. The risk of Dutch disease is that the increase in the price of nontradables (local construction materials,

\footnotetext{
${ }^{2}$ The estimates in Table 2 do not properly treat transactions between the oil and non-oil sectors. It has proven a major challenge for those compiling Chad's balance of payments statistics to obtain the necessary information to adequately register oil-sector-related flows, especially financial flows internal to the consortium.
} 
services, food production for local consumption) would squeeze key and potential tradables, depriving the economy of an important source of employment and technological change. The findings of this paper suggest that the priority for the non-oil economy is to remove obstacles to growth, thereby improving the business environment in which the private sector must operate. Even before oil production, cotton was mired in problems that have not been worsened by oil production. However, oil rents may have reduced the incentives to proceed with the reform of the cotton sector.

\begin{tabular}{|c|c|c|c|c|c|c|c|c|c|c|c|c|c|c|c|}
\hline & 1994 & 1995 & 1996 & 1997 & 1998 & 1999 & 2000 & 2001 & 2002 & 2003 & 2004 & 2005 & 2006 & 2007 & 2008 \\
\hline & \multicolumn{15}{|c|}{ (in percent of total GDP) } \\
\hline $\begin{array}{l}\text { Current account balance } \\
\text { excl. oil sector }\end{array}$ & $\begin{array}{l}-9.7 \\
-8.5\end{array}$ & $\begin{array}{l}-8.4 \\
-7.4\end{array}$ & $\begin{array}{l}-9.7 \\
-8.4\end{array}$ & $\begin{array}{r}-11.4 \\
-9.9\end{array}$ & $\begin{array}{l}-8.5 \\
-5.5\end{array}$ & $\begin{array}{r}-10.7 \\
-5.3\end{array}$ & $\begin{array}{r}-15.4 \\
-9.3\end{array}$ & $\begin{array}{r}-31.8 \\
-8.0\end{array}$ & $\begin{array}{l}-94.7 \\
-14.7\end{array}$ & $\begin{array}{r}-48.8 \\
-8.3\end{array}$ & $\begin{array}{r}-17.4 \\
-5.2\end{array}$ & $\begin{array}{r}2.4 \\
-4.4\end{array}$ & $\begin{array}{l}-9.0 \\
-4.5\end{array}$ & $\begin{array}{r}-10.5 \\
-8.0\end{array}$ & $\begin{array}{r}-9.6 \\
-10.9\end{array}$ \\
\hline $\begin{array}{l}\text { Trade balance } \\
\text { excl. oil sector }\end{array}$ & $\begin{array}{l}-7.0 \\
-5.8\end{array}$ & $\begin{array}{l}-2.3 \\
-1.3\end{array}$ & $\begin{array}{r}-0.3 \\
1.0\end{array}$ & $\begin{array}{r}-0.6 \\
0.9\end{array}$ & $\begin{array}{r}-0.8 \\
2.2\end{array}$ & $\begin{array}{r}-1.4 \\
4.0\end{array}$ & $\begin{array}{r}-4.1 \\
2.0\end{array}$ & $\begin{array}{r}-19.1 \\
-0.5\end{array}$ & $\begin{array}{r}-66.2 \\
-5.3\end{array}$ & $\begin{array}{l}-8.4 \\
-1.4\end{array}$ & $\begin{array}{r}28.0 \\
-4.5\end{array}$ & $\begin{array}{r}37.4 \\
-4.1\end{array}$ & $\begin{array}{r}32.8 \\
-5.0\end{array}$ & $\begin{array}{r}30.4 \\
-6.7\end{array}$ & $\begin{array}{l}31.7 \\
-8.5\end{array}$ \\
\hline $\begin{array}{l}\text { Exports } \\
\text { oil exports }\end{array}$ & $\begin{array}{r}11.0 \\
0.0\end{array}$ & $\begin{array}{r}16.9 \\
0.0\end{array}$ & $\begin{array}{r}14.9 \\
0.0\end{array}$ & $\begin{array}{r}15.2 \\
0.0\end{array}$ & $\begin{array}{r}15.3 \\
0.0\end{array}$ & $\begin{array}{r}15.8 \\
0.0\end{array}$ & $\begin{array}{r}13.2 \\
0.0\end{array}$ & $\begin{array}{r}11.0 \\
0.0\end{array}$ & $\begin{array}{l}9.3 \\
0.0\end{array}$ & $\begin{array}{r}22.0 \\
8.6\end{array}$ & $\begin{array}{l}49.5 \\
39.2\end{array}$ & $\begin{array}{l}53.5 \\
46.2\end{array}$ & $\begin{array}{l}54.1 \\
47.1\end{array}$ & $\begin{array}{l}52.4 \\
45.6\end{array}$ & $\begin{array}{l}54.0 \\
47.4\end{array}$ \\
\hline excl. oil sector & 11.0 & 16.9 & 14.9 & 15.2 & 15.3 & 15.8 & 13.2 & 11.0 & 9.3 & 13.4 & 10.3 & 7.3 & 7.0 & 6.8 & 6.6 \\
\hline Imports & -18.0 & -19.2 & -15.2 & -15.9 & -16.1 & -17.2 & -17.3 & -30.2 & -75.5 & -30.3 & -21.6 & -16.2 & -21.3 & -22.0 & -22.3 \\
\hline oil-sector imports & -1.2 & -1.0 & -1.3 & -1.5 & -3.0 & -5.4 & -6.1 & -18.7 & -60.9 & -15.6 & -6.8 & -4.8 & -9.4 & -8.5 & -7.1 \\
\hline excl. oil sector & -16.8 & -18.2 & -13.9 & -14.3 & -13.1 & -11.8 & -11.2 & -11.5 & -14.6 & -14.7 & -14.8 & -11.4 & -12.0 & -13.5 & -15.2 \\
\hline $\begin{array}{l}\text { Services } \\
\quad \text { excl. oil sector }\end{array}$ & $\begin{array}{l}-10.3 \\
-10.3\end{array}$ & $\begin{array}{l}-9.5 \\
-9.5\end{array}$ & $\begin{array}{l}-11.3 \\
-11.3\end{array}$ & $\begin{array}{l}-11.6 \\
-11.6\end{array}$ & $\begin{array}{l}-10.0 \\
-10.0\end{array}$ & $\begin{array}{l}-11.5 \\
-11.5\end{array}$ & $\begin{array}{l}-13.7 \\
-13.7\end{array}$ & $\begin{array}{l}-15.9 \\
-10.7\end{array}$ & $\begin{array}{l}-30.4 \\
-11.3\end{array}$ & $\begin{array}{l}-28.2 \\
-10.6\end{array}$ & $\begin{array}{r}-36.8 \\
-8.9\end{array}$ & $\begin{array}{r}-30.5 \\
-5.9\end{array}$ & $\begin{array}{r}-27.8 \\
-4.2\end{array}$ & $\begin{array}{r}-27.8 \\
-5.8\end{array}$ & $\begin{array}{r}-24.4 \\
-5.9\end{array}$ \\
\hline $\begin{array}{l}\text { ncome } \\
\quad \text { excl. oil sector }\end{array}$ & $\begin{array}{l}-0.7 \\
-0.7\end{array}$ & $\begin{array}{l}-0.4 \\
-0.4\end{array}$ & $\begin{array}{l}-0.6 \\
-0.6\end{array}$ & $\begin{array}{l}-1.1 \\
-1.1\end{array}$ & $\begin{array}{l}-1.2 \\
-1.2\end{array}$ & $\begin{array}{l}-1.0 \\
-1.0\end{array}$ & $\begin{array}{l}-1.2 \\
-1.2\end{array}$ & $\begin{array}{l}-1.3 \\
-1.3\end{array}$ & $\begin{array}{l}-3.0 \\
-3.0\end{array}$ & $\begin{array}{r}-16.4 \\
-0.6\end{array}$ & $\begin{array}{r}-13.4 \\
3.2\end{array}$ & $\begin{array}{r}-9.8 \\
0.3\end{array}$ & $\begin{array}{r}-18.3 \\
0.3\end{array}$ & $\begin{array}{r}-17.1 \\
0.4\end{array}$ & $\begin{array}{r}-19.9 \\
0.4\end{array}$ \\
\hline Current transfers & 8.2 & 3.8 & 2.5 & 1.8 & 3.4 & 3.2 & 3.6 & 4.5 & 4.9 & 4.2 & 5.0 & 5.3 & 4.4 & 4.0 & 3.2 \\
\hline $\begin{array}{l}\text { Capital and financial account } \\
\text { excl. oil sector }\end{array}$ & $\begin{array}{l}10.9 \\
10.9\end{array}$ & $\begin{array}{l}10.4 \\
10.4\end{array}$ & $\begin{array}{l}11.3 \\
11.3\end{array}$ & $\begin{array}{l}10.2 \\
10.2\end{array}$ & $\begin{array}{l}5.5 \\
6.3\end{array}$ & $\begin{array}{l}8.4 \\
8.8\end{array}$ & $\begin{array}{r}16.3 \\
8.2\end{array}$ & $\begin{array}{r}32.8 \\
6.1\end{array}$ & $\begin{array}{l}98.0 \\
51.7\end{array}$ & $\begin{array}{l}45.3 \\
19.4\end{array}$ & $\begin{array}{r}17.9 \\
7.4\end{array}$ & $\begin{array}{r}-1.8 \\
0.0\end{array}$ & $\begin{array}{r}14.9 \\
4.6\end{array}$ & $\begin{array}{r}14.2 \\
4.2\end{array}$ & $\begin{array}{r}16.8 \\
2.6\end{array}$ \\
\hline oil sector FDI & 0.0 & 0.0 & 0.0 & 0.0 & -0.8 & -0.4 & 8.1 & 26.7 & 46.3 & 25.9 & 10.5 & -1.8 & 10.3 & 10.0 & 14.2 \\
\hline \multicolumn{16}{|l|}{ Memorandum items: } \\
\hline Dil sales (millions of barrels) & $\ldots$ & $\ldots$ & $\ldots$ & $\ldots$ & $\ldots$ & $\ldots$ & $\ldots$ & $\ldots$ & $\ldots$ & 8.6 & 61.3 & 56.3 & 55.9 & 52.4 & 46.5 \\
\hline Chadian oil price (ex-Kribi; \$/barrel) & $\ldots$ & $\ldots$ & $\ldots$ & $\ldots$ & $\ldots$ & $\ldots$ & $\ldots$ & $\ldots$ & $\ldots$ & 17.0 & 18.8 & 33.3 & 42.1 & 51.1 & 75.8 \\
\hline Nominal GDP (billions of US\$) & 1.2 & 1.4 & 1.6 & 1.6 & 1.7 & 1.5 & 1.4 & 1.7 & 2.0 & 2.7 & 4.4 & 5.9 & 6.3 & 7.0 & 8.4 \\
\hline
\end{tabular}

11. The analysis of the prices of nontradables in the CPI finds no sign of Dutch disease. The only variable showing any evidence is the increase of the wage bill, which went from 5 percent of non-oil GDP in 2000 to $9^{1 / 4} / 4$ percent in 2008 , with half of that increase explained by an increase of military wages. Total public sector employment increased from 57,000 in 2001 to 117,000 in 2008 , and the average wage in real terms increased by about 47 percent. Though oil production is an enclave economy with not much Figure 2. Chad: Price of Key Non-tradables (index, base 1994) impact in shifting labor, the expansion of government expenditures during the oil boom, which fueled the rise in the wage bill, could lead to a shift in labor from other sectors to the public sector. However, there 
is not much evidence that these resources are coming from active non-oil sectors rather than from a pool of previously idle labor.

12. Though the quality of investment is not optimal, the use of oil resources to build needed infrastructure and invest in education and health, by helping build up the non-oil sector, addresses the risk of Dutch disease. ${ }^{3}$ It appears that labor availability and costs in the agricultural, especially livestock, sectors have not been affected by the emergence of an oil sector or expansion of government employment. Rather, increased government spending has helped agriculture by providing essential infrastructure.

\section{ChaD's Real EFFECTIVE ExCHANGE RATE}

13. This section assesses Chad's real effective exchange rate (REER) using the methodologies designed by the Consultative Group on the Exchange Rate (CGER): (i) the equilibrium real exchange rate approach; (ii) the macroeconomic balance approach; and (iii) the external sustainability approach. However, poor data quality makes it difficult to conduct a comprehensive quantitative analysis. Not only are its external sector data unreliable but Chad also has a substantial amount of unrecorded trade with Nigeria and Cameroon that would not be reflected in such statistics as the REER and the terms of trade. This consists mainly of refined oil and small manufactures smuggled into to Chad and some livestock exported from Chad. The REER appreciated by $16 \frac{1}{2}$ percent over $2000-07$, because domestic inflation in Chad was higher than in trading partners and the Euro appreciated significantly against the dollar. The results of the three approaches are summarized in the below table.

Table 3. Chad: Real Exchange Rate Assessment

\begin{tabular}{lcc}
\hline Method & Assessment & $\begin{array}{c}\text { Overvaluation } \\
(+) \text { Undervaluation (-) } \\
\text { (In Percent) }\end{array}$ \\
\hline Equilibrium REER & Inconclusive & - \\
Macroeconomic Balance & Overvalued & 3.6 \\
External Sustainability & Overvalued & 2.3 \\
\hline
\end{tabular}

\footnotetext{
${ }^{3}$ A paper by Levy (2007) reaches similar conclusion arguing that policies supporting vulnerable parts of the economy, notably irrigation and road infrastructure, prevent the occurrence of Dutch Disease and creates the opportunity for development and poverty reduction.
} 


\section{A. The Equilibrium Real Exchange Rate Approach}

14. This backward-looking approach is designed to estimate the level at which the real effective exchange rate is aligned with fundamentals. The methodology directly estimates an equilibrium real exchange rate and compares it with the current exchange rate to derive conclusions on any needed exchange rate adjustment.

The equilibrium REER can be estimated using the following basic specification:

Ln REER $=\alpha+\beta_{1} \operatorname{Ln} \mathrm{TOT}_{\mathrm{t}}+\beta_{2} \mathrm{LnProd}_{\mathrm{t}}+\beta_{3} \mathrm{LnOpn}_{\mathrm{t}}+\beta_{4} \mathrm{Ln} \mathrm{GC}_{\mathrm{t}}+\mu$

where:

REER: Real effective exchange rate

TOT: Terms of trade

Prod: Productivity

Opn: Openness

GC: The ratio of government consumption to GDP

$\mu$ : Error term

15. The model was estimated using the autoregressive distributed lag (ARDL) technique, which allows to test for cointegrating relationships and is appropriate for short time series. The ARDL technique estimates the long-run parameters and determines whether there is a cointegrating relationship among regressors at different lag definitions. The augmented Dickey-Fuller, Philips and Perron, and Zivot and Andrews tests (see Table 4 for results) enables to detect the presence of unit roots and structural breaks in the series. The Philips and Perron test also enables through a nonparametric process to correct error autocorrelation and heterokedasticity. The hypothesis of the presence of unit roots is rejected after applying first differences to the variables because in the Philips-Perron and the Zivot-Andrews tests the values are below the critical benchmark of significance when the variables are not differentiated.

16. The best equation at two lags does not give enough evidence that a cointegrating vector exists because productivity is the only significant variable. The REER was overvalued by an average of $16 \frac{1}{2}$ percent for $2000-07$, a period that coincides with the advent of the oil era (see Appendix Figure 3). However, given the lack of significance of most of the variables and the wrong sign for terms of trade and openness, no firm conclusions can be drawn from the estimation. The wrong sign of the terms of trade is puzzling and only could be explained by poor data or the fact that spending from the oil boom is increasing imports substantially and thus neutralizing the effects on the REER. 
Table 4. ARDL on Base Specification with Different Number of Lags

\begin{tabular}{lccc}
\hline \multirow{2}{*}{ Long Run Coefficients } & \multicolumn{3}{c}{ Dependent Variable: In(REER) } \\
\cline { 2 - 4 } & Two Lags & One Lag & Three Lags \\
\hline \multirow{2}{*}{ In (Terms of Trade) } & -0.350 & -0.377 & -0.560 \\
& 1.159 & 0.823 & $2.765^{* *}$ \\
In (Productivity) & 0.649 & 0.647 & 0.467 \\
& $-7.384^{* * *}$ & $-4.846^{* * *}$ & $-7.924^{* * *}$ \\
In (Government Consumption) & -0.099 & 0.009 & -0.072 \\
& 0.489 & -0.030 & 0.529 \\
In (Openness) & -0.110 & 0.118 & 0.256 \\
& 0.491 & -0.347 & $-1.704^{*}$ \\
Constant & 6.655 & 5.625 & 6.049 \\
& & & \\
Observations & 26 & 26 & 26 \\
R-squared & 0.93 & 0.90 & 0.97 \\
F-Statistic for Bound Test ${ }^{1}$ & 3.54 & 25.30 & 4.23 \\
Akaike Information Criteria & -45.90 & -48.81 & -55.62 \\
Schwarz Information Criteria & -27.03 & -35.85 & -31.24 \\
Error Correction & -0.70 & -0.46 & -0.97 \\
\hline Zstatistics in parentheses. & & &
\end{tabular}

Z statistics in parentheses.

${ }^{* * *} p<0.01,{ }^{* *} p<0.05,{ }^{*} p<0.1$

${ }^{1}$ Upper level bounds are 6.36 for two lags, 7.84 for one lag, 5.61 for three lags.

17. A second approach is to drop all the nonsignificant variables and leave only productivity. The equilibrium REER estimated with the ARDL technique at two lags shows an average undervaluation of 6.1 percent for 2000-07 (see Appendix Figure 4). The limitation of this approach is that it relates the REER to only one fundamental, making it difficult to draw definite conclusions.

Ln REER $=4.5+0.62 \mathrm{LN} \operatorname{Prod}_{t}$

Z statistics $\quad(-1.6)$

18. A third approach imposes the coefficients from a CEMAC pool single time-series estimation to fit the equilibrium exchange rate with Chadian data (Table 5). The results from using the long-term CEMAC coefficients show an average moderate overvaluation of 5 percent for $2000-07$.

19. Although the REER has appreciated since 2000 there is no solid evidence that it is inconsistent with fundamentals. Results from the equilibrium exchange rate approach were inconclusive, showing no significant under- or overvaluation. 
Table 5. CEMAC Estimation

\begin{tabular}{ll}
\hline Long Run Coefficients & Dependent Variable: in(REER) \\
\cline { 2 - 2 } & Johansen single time series \\
\hline in (Terms of Trade) & 0.63 \\
in (Productivity) & $5.14^{* * *}$ \\
in (Government Consumption) & 0.64 \\
in (Openness) & $6.98^{* * *}$ \\
in (Investment) & -0.59 \\
Constant & $-3.3^{* * *}$ \\
Error-Correction Term Estimates & -0.80 \\
D (in REER) & $-4.59^{* * *}$ \\
& -0.74 \\
\hline$Z$ & $-3.56^{* * *}$ \\
\hline
\end{tabular}

Z statistics in parentheses.

${ }^{* * *} p<0.01,{ }^{* *} p<0.05,{ }^{*} p<0.1$

\section{B. The Macroeconomic Balance Approach}

20. This three-stage approach computes how much exchange rate adjustment is needed to achieve a sustainable current account. It first defines an underlying current account, then defines a saving-investment norm, and finally computes the size of the REER adjustment needed to bring to equilibrium the current account and the saving investment norm. The basic working identity is the saving investment equation:

Current account $=$ Saving investment

21. There are several techniques to estimate the underlying current account. The CEMAC consultation SIP paper finds that in most CEMAC countries the difference between the underlying and the projected current account is not statistically significant. ${ }^{4} \mathrm{We}$ assume that the underlying current account is -8.8 percent of GDP, which is the long-term current account (2010-28) after the oil production and investment spikes have subsided. Other approaches, such as smoothing filters or moving averages, are distorted by the spikes at the start of oil production in Chad. For instance, the current account widened sharply at the beginning of the 2000s when the pipeline was being constructed. Since data limitations make

\footnotetext{
${ }^{4}$ IMF, “CEMAC. External Stability and Exchange Rate Assessment in an Oil-Dependent Region,” Selected Issues paper for the 2008 Article IV consultation.
} 
it impossible to run a regression on the current account fundamentals, it is computed using panel estimates of current account regressions based on previous research from developing countries. We use the CGER (2008) paper's hybrid pooled estimations to estimate the norm as Table 6 below shows.

22. Finally, using elasticity estimations for countries with similar profiles, ${ }^{5}$ the impact of devaluation on the current account is computed by obtaining the elasticity of the current account with respect to the REER. Here the macroeconomic-balance approach shows a slight overvaluation of the REER of about $23 / 4$ percent (Tables 7 and 8 ).

Table 6. Chad: Savings-Investment-Current Account Norm

\begin{tabular}{lccc}
\hline & $\begin{array}{c}\text { Medium- } \\
\text { and Long- } \\
\text { Term Value }\end{array}$ & $\begin{array}{c}\text { CGER } \\
\text { Coefficient }\end{array}$ & Impact \\
\hline Gariable & 2.5 & 0.19 & 0.5 \\
Government budget balance & 2.5 & -1.03 & -2.5 \\
Lagulation growth & -9.0 & 0.37 & -3.3 \\
Relative income & 1.4 & 0.02 & 0.1 \\
Output growth & 4.0 & -0.16 & -0.6 \\
Youth dependency ratio & 2.0 & & \\
Initial NFA & 5.0 & & \\
\hline \multicolumn{1}{c}{ Norm } & & & -5.8 \\
\hline
\end{tabular}

Table 7. Chad: Impact of Devaluation on the Current Account

\begin{tabular}{lc}
\hline Export elasticity & -1.0 \\
\hline Import elasticity & 0.8 \\
Share of exports in GDP * & 0.5 \\
Share of imports in GDP * & 0.4 \\
Elasticity** & -.82 \\
Required percentage change in the REER to & -1.2 \\
improve the current account by 1 percentage point & \\
of GDP & \\
\hline${ }^{*}$ Average 2007-12. & \\
& ${ }^{* *}$ Elasticity= (Export elasticity * Share of exports in GDP) - (Import elasticity * Share of imports in \\
GDP).
\end{tabular}

\footnotetext{
${ }^{5}$ Estimate of imports and exports with respect to changes in the REER are in the order of 0.5 to 1.5 . We use here estimates from IMF, "Niger- Selected Issues" (www.imf.org) and IMF, WAEMU (www.imf.org).
} 
Table 8. Chad: Results of the Macroeconomic Balance Approach

$\begin{array}{lc}\text { Underlying current account } & -8.8 \\ \text { Current account - Saving investment norm } & -5.8 \\ \text { Needed adjustment in the current account } & 3.0 \\ \text { Implied overvaluation } & 3.6 \%\end{array}$

\section{External Sustainability Approach.}

23. Assuming no capital gains, zero errors and omissions, and no capital transfers, the current account that stabilizes net foreign assets (NFAs) at the benchmark level, $b^{s}$, is given by

$$
c a^{s}=\frac{g+\pi}{(1+g)(1+\pi)} \cdot b^{s}
$$

where $g$ is the GDP growth rate and $\pi$ is the inflation rate. The key issue is selecting a benchmark level for NFAs: using a backward-looking benchmark such as the NFA level of previous years is not appropriate because most of the variables are distorted by the first years of oil production. The country has a relatively short production horizon (30 years) with output picking up in the first years and then declining gradually. It is appropriate to select a benchmark based on the key components of the NFA position (NFAP) in the long run, including the level of reserves, external debt, and particularly FDI, which in Chad plays a key role in financing the current account because constant investment is needed to maintain a given level of production.

24. The NFAP (see Table 9) is based on the Debt Sustainability Analysis (DSA). FDI and external debt represent the average long-term levels (2010-28) used in the DSA. External debt is therefore projected to decline over time as debt is repaid. The stock of FDI as of 2007 is also projected to decrease as oil production gradually declines.

Table 9. Chad: Net Foreign Assets Target (In percent of GDP)

\begin{tabular}{lccc}
\hline & Niger's Benchmark & Chad 2007 & Chad's benchmark \\
\hline Net Foreign Assets Position (NFAP) & -86.0 & $-\mathbf{1 1 4 . 9}$ & -98.0 \\
Assets & 12 & 12.8 & 5 \\
Direct Investment Abroad & 0 & 0 & 0 \\
Portfolio Investment & 2 & 0 & 0 \\
Reserves & 10 & 12.8 & 5 \\
Debt & 0 & 0 & 0 \\
Liabilities & -98.0 & -127.7 & -103.0 \\
Direct Investment * & 40 & 105.5 & 86.5 \\
Portfolio Investment & 8 & 0 & 0 \\
Debt ** & 50 & 22.2 & 16.5 \\
\hline
\end{tabular}

${ }^{*}$ For Chad long term average 2010-28.

${ }^{* *}$ For Chad, long-term average $2010-28$ in the DSA. 
25. Selecting as benchmark the NFAP target of -95 percent of GDP, the current account balance that would stabilize that is computed using the following assumptions: $g: 4.5$ percent (long-term growth); and $\pi: 3$ percent (the CEMAC convergence criterion). Using recent oil price assumptions the long-term current account is slightly higher than the stabilizing current account, which implies a moderate overvaluation of $2^{1 / 4}$ percent. ${ }^{6}$

Table 10. Macroeconomic Balance Results

(percent of GDP, except for the REER)

\begin{tabular}{ccccc}
\hline NFAP & Stabilizing CA & $\begin{array}{c}\text { Long-term CA } \\
\text { Average }(2010-28)\end{array}$ & Difference & $\begin{array}{c}\text { Implied Over(+) Under(-) } \\
\text { valuation of the REER }\end{array}$ \\
-98 & -7.0 & -8.8 & 1.9 & $2.3 \%$ \\
\hline
\end{tabular}

26. The conclusion that can be drawn from using all three methods is that there is no solid evidence that the REER is not in line with fundamentals. Some evidence was found of a modest overvaluation of the exchange rate by 2 to 4 percent.

\section{NON-EXCHANGE RATE INDICATORS OF COMPETITIVENESS}

27. In addition to the exchange rate assessment, other determinants of competitiveness are associated with transaction costs and the environment in which the private sector must operate. Chad's ability to compete in the international marketplace is very much influenced by the quality of its business climate. In a competitive economy the private sector will be able to exploit the country's comparative advantages to efficiently produce goods and services that can then be traded for goods and services produced more efficiently abroad. To do this the private sector needs stable economic policy, a legal system that enforces property rights, quality economic regulation, and an adequate supply of public goods, such as education, health, and energy and transportation infrastructure. The ability of a government to create such an environment is determined by the quality of its governance.

28. The recognition that poor governance is one of the main obstacles to development has given rise over the past decade to numerous indicators that measure governance in its many facets. $^{7}$ The conclusion from the better-known of these indicators is that the quality of governance in Chad is extremely poor. Since developing countries generally score low on governance indicators, Chad's performance within the group of low-income countries is telling (see Table 11). Chad ranks consistently in the bottom quartile of major governance indicators compared to other low-income countries. The World Bank's Country Policy and

\footnotetext{
${ }^{6}$ The implied adjustment is computed by using the elasticities and parameter from the macroeconomic balance approach, in which the REER has to change by 1.2 percent for the current account to change by 1 percent.

7 The UNDP's Governance Indicators - A Users' Guide informatively describes many governance indicators and how they might be used (see http://www.undp.org/oslocentre/flagship/governance_indicators_project.html).
} 
Institutional Assessment (CPIA) is an index of government effectiveness based on assessments by World Bank staff intimately familiar with the country. The Bank's Doing Business indicators focus on the ease of setting up and running a business based on responses from local observers familiar with the country's business climate. The World Bank Institute (WBI) Governance Indicators aggregates the results of many perception surveys and expert reviews into an assessment of performance on six governance dimensions. The Transparency International (TI) Corruption Perception Index is similarly an aggregate index. And the United Nations Development Programme's (UNDP's) Human Development Index combines indicators of economic performance with indicators of a country's success in satisfying the basic human needs of its people. ${ }^{8}$

Table 11. Chad: Relative Performance on Governance Indicators ${ }_{1 /}$

\begin{tabular}{lcccc}
\hline & $\begin{array}{c}\text { ratings } \\
2007\end{array}$ & $\begin{array}{c}\text { position } \\
\text { from } \\
\text { bottom }\end{array}$ & $\begin{array}{c}\text { number } \\
\text { of } \\
\text { countries }\end{array}$ & quartile \\
Overall CPIA (WB) & 2.575 & 8 & 74 & bottom \\
Ease of Doing Business (WB) & 172 & 7 & 76 & bottom \\
Governance Indicators (WBI) & & & & \\
$\quad$ Control of Corruption & -1.22 & 9 & 78 & bottom \\
$\quad$ Government Effectivness & -1.45 & 8 & 78 & bottom \\
$\quad$ Rule of Law & -1.40 & 11 & 78 & bottom \\
$\quad$ Political Stability & -1.96 & 10 & 78 & bottom \\
$\quad$ Regulatory Quality & -1.16 & 16 & 78 & bottom \\
$\quad$ Voice and Accountability & -1.43 & 10 & 78 & bottom \\
Human Development Index (UNDP) & 0.388 & 8 & 74 & bottom \\
Corruption Perception Index (TI; 2006) & 2 & 5 & 62 & bottom \\
\hline
\end{tabular}

$1 /$ Rating relative to group of IDA-eligible Low Income Countries.

\section{A. Doing Business Indicators}

29. The Doing Business Indicators (DB) are widely used for assessing a country's business climate. ${ }^{9}$ The DB's popularity is due to the fact that all the indicators are quantifiable, they are detailed enough to identify specific areas requiring policy attention, and can be used to measure performance over time. The DB measures performance on 11 critical aspects of starting and running a successful business. Again, a comparison of Chad's performance relative to its peers may be particularly informative.

\footnotetext{
${ }^{8}$ For the CPIA, see http://go.worldbank.org/AL5SDP3T90. For the other indicators listed, see the World Bank Institute's Interactive Governance Site (http://go.worldbank.org/W0DI8LZMD0 ).

${ }^{9}$ See the World Bank website at http://rru.worldbank.org/businessplanet/.
} 
30. Table 12 compares Chad's performance on the DB with that of the other CEMAC countries plus neighboring Niger and Nigeria, which are not members of CEMAC. The countries are ranked within the group of 46 sub-Saharan countries. The first column, Ease of Doing Business, shows the composite ranking. Chad does particularly poorly in permitting a business to start up and in enforcing contracts. Its best relative performance is in dealing with construction permits. The data also point to a regional effect in that on the overall indicator Chad and its neighbors, except for Nigeria, all fall within the bottom two quartiles compared to other sub-Saharan countries.

Table 12. Chad: Ranking onDoing Business Within Sub-Saharan Africa/

\begin{tabular}{|c|c|c|c|c|c|c|c|c|c|c|c|}
\hline & $\begin{array}{l}\text { Ease of Doing } \\
\text { Business Rank }\end{array}$ & $\begin{array}{l}\text { Starting a } \\
\text { Business }\end{array}$ & $\begin{array}{c}\text { Dealing with } \\
\text { Construction } \\
\text { Permits }\end{array}$ & $\begin{array}{r}\text { Employing } \\
\text { Workers }\end{array}$ & $\begin{array}{r}\text { Registering } \\
\text { Property }\end{array}$ & $\begin{array}{r}\text { Getting } \\
\text { Credit }\end{array}$ & $\begin{array}{l}\text { Protecting } \\
\text { Investors }\end{array}$ & $\begin{array}{r}\text { Paying } \\
\text { Taxes }\end{array}$ & $\begin{array}{c}\text { Trading } \\
\text { Across } \\
\text { Borders } \\
\end{array}$ & $\begin{array}{l}\text { Enforcing } \\
\text { Contracts }\end{array}$ & $\begin{array}{l}\text { Closing a } \\
\text { Business }\end{array}$ \\
\hline Chad & 40 & 45 & 11 & 27 & 22 & 27 & 20 & 27 & 34 & 39 & 34 \\
\hline Cameroon & 32 & 40 & 36 & 24 & 25 & 19 & 17 & 42 & 19 & 43 & 15 \\
\hline CAR & 45 & 29 & 27 & 31 & 23 & 19 & 20 & 45 & 45 & 40 & 34 \\
\hline Republic of Congo & 43 & 33 & 10 & 40 & 43 & 19 & 32 & 46 & 46 & 36 & 21 \\
\hline Equatorial Guinea & 34 & 41 & 15 & 45 & 7 & 19 & 26 & 38 & 18 & 9 & 34 \\
\hline Gabon & 24 & 27 & 8 & 33 & 37 & 19 & 32 & 19 & 14 & 32 & 25 \\
\hline Nigeria & 12 & 10 & 34 & 2 & 46 & 7 & 6 & 25 & 23 & 16 & 13 \\
\hline Niger & 38 & 34 & 38 & 38 & 8 & 27 & 32 & 25 & 41 & 26 & 27 \\
\hline
\end{tabular}

$1 /$ Rankings are within group of 46 Sub-Saharan African countries.

31. The Doing Business Indicators permit analysis at a detailed level since the 11 topics are measured with the help of 41 specific indicators. Table 13 compares Chad's performance with that of other sub-Saharan countries and with the OECD countries, which can be considered as adhering to international best practice. Compared with other countries in the region, Chad's performance has some favorable elements: It does relatively well in "dealing with licenses," which relates to "the procedures, time, and costs to build a warehouse, including obtaining necessary licenses and permits, completing required notifications and inspections, and obtaining utility connections." Chad also does relatively well on several labor market indicators, and on the time it takes to register property (although the cost is high). On the other hand, Chad performs particularly poorly on procedures, time, and cost for starting a business, and on the time and cost of importing and exporting, which are staggering. The cost of exporting a container is $\$ 4,867$ and it takes 78 days, compared with $\$ 1,660$ and 36 days for the region. Importing is even more costly and time-consuming: $\$ 5,520$ per container and 102 days compared with $\$ 1,986$ and 44 days. And even the subSaharan average is far higher than in the OECD, where exporting or importing a container costs less than $\$ 1,000$ and on average takes less than 10 days.

\section{BARRIERS TO INTERNAL AND EXTERNAL TRADE}

32. Internal and external trade are closely related. The ease with which economic operators can trade within their country has a great impact on their business costs and therefore on their external competitiveness. Internal trade determines the resilience of the country's supply side. For that reason, a comprehensive trade diagnostic carried out by six 
international institutions led by the World Bank, the Diagnostic Trade and Integration Study (DTIS) of January 2007, looked at both internal and external trade. ${ }^{10}$ Its purpose was to help the government define a strategy and an integrated approach for raising Chad's participation in regional and global markets. The DTIS provided a rich analysis of the many factors that adversely affect the country's business climate and impair trade. Notwithstanding the improved outlook for growth and poverty reduction thanks to the additional resources from oil, the DTIS concluded, major reforms within Chad's borders are necessary to raise the growth rate sustainably and make inroads into poverty. The main constraints to growth it identified were inadequate infrastructure and public services; deficiencies in the business climate; weak governance, and bad collaboration between the public and private sectors.

33. The DTIS observed that while constraints on the production of goods and services are the more serious hindrance to trade integration, there is still much to be done to remove obstacles to exports and thus encourage economic diversification. The DTIS recommends simplifying and reducing the tariff regime, such as shrinking the number of categories of goods from four to three; lowering the maximum common external tariff (CET) from 30 to 20 percent; and implementing a duty drawback scheme for exporters.

34. Chad is beset with barriers to trade within its borders. According to the DTIS, production in the sectors where Chad has the greatest comparative natural advantage-cotton and livestock - is suboptimal. Cotontchad, the country's sole cotton buyer, is virtually bankrupt. Its equipment is inadequate and its management is bad. As a result, it does not fulfill its role of buying and transporting cotton. The problems are compounded by fraud, black market operations, and extortion. There is a serious risk that farmers will abandon cotton production. The extra income that could be generated with improvements in the cotton sector would spill over into other parts of agriculture, such as livestock, where the country's comparative advantage can be better exploited.

\footnotetext{
${ }^{10}$ The DTIS was carried out in the context of the Integrated Framework supported by six institutions, including the World Bank, the IMF, the UNDP and the WTO. For Chad's DTIS (Tchad-Étude diagnostique sur l'intégration commerciale) see http://www.integratedframework.org/countries/chad.htm .
} 
Table 13. Chad: Doing Business Indicators

\begin{tabular}{|c|c|c|c|c|}
\hline & Chad & Region & OECD & $\begin{array}{l}\text { Chad better } \\
\text { than region }\end{array}$ \\
\hline \multicolumn{5}{|l|}{ Starting a Business } \\
\hline Procedures (number) & 19.0 & 10.8 & 6.0 & \\
\hline Duration (days) & 75.0 & 56.3 & 14.9 & \\
\hline Cost (\% GNI per capita) & 188.8 & 148.1 & 5.1 & \\
\hline \multicolumn{5}{|l|}{ Dealing with Licenses } \\
\hline Procedures (number) & 9.0 & 18.1 & 14.0 & Better \\
\hline Duration (days) & 181.0 & 262.5 & 153.3 & Better \\
\hline Cost ( $\%$ of income per capita) & 1,064 & 2,549 & 62.2 & Better \\
\hline \multicolumn{5}{|l|}{ Employing Workers } \\
\hline Difficulty of Hiring Index & 39.0 & 41.7 & 25.2 & Better \\
\hline Rigidity of Hours Index & 60.0 & 43.9 & 39.2 & \\
\hline Difficulty of Firing Index & 40.0 & 42.2 & 27.9 & Better \\
\hline Rigidity of Employment Index & 46.0 & 42.6 & 30.8 & \\
\hline Nonwage labor cost ( $\%$ of salary) & 21.0 & 12.3 & 20.7 & \\
\hline Firing costs (weeks of wages) & 36.0 & 68.3 & 25.7 & Better \\
\hline \multicolumn{5}{|l|}{ Registering Property } \\
\hline Procedures (numbered) & 6.0 & 7.0 & 4.9 & Better \\
\hline Duraction (days) & 44.0 & 104.6 & 28.0 & Better \\
\hline Cost ( $\%$ of property value) & 21.2 & 11.1 & 4.6 & \\
\hline \multicolumn{5}{|l|}{ Getting Credit } \\
\hline Legal Rights Index & 3.0 & 4.0 & 6.4 & \\
\hline Credit Information Index & 1.0 & 1.3 & 4.8 & \\
\hline Public registry coverage ( $\%$ adults) & 0.2 & 2.1 & 8.6 & \\
\hline Private bureau coverage ( $\%$ adults) & - & 4.5 & 59.3 & \\
\hline \multicolumn{5}{|l|}{ Protecting Investors } \\
\hline Disclosure Index & 6.0 & 4.7 & 6.4 & Better \\
\hline Director Liability Index & 1.0 & 3.1 & 5.1 & \\
\hline Shareholder Suits Index & 5.0 & 5.0 & 6.5 & \\
\hline Investor Protection Index & 4.0 & 4.3 & 6.0 & \\
\hline \multicolumn{5}{|l|}{ Paying Taxes } \\
\hline Payments (number) & 54.0 & 38.7 & 15.1 & \\
\hline Time (hours) & 122.0 & 321.2 & 183.3 & Better \\
\hline Profit tax (\%) & 31.3 & 21.4 & 20.0 & \\
\hline Labor tax and contributions (\%) & 23.9 & 13.3 & 22.8 & \\
\hline Other taxes (\%) & 8.5 & 33.3 & 3.4 & \\
\hline Total tax rate (\% profit) & 63.7 & 68.0 & 46.2 & \\
\hline \multicolumn{5}{|l|}{ Trading Across Borders } \\
\hline Documents for export (number) & 6.0 & 8.1 & 4.5 & Better \\
\hline Time for export (days) & 78.0 & 35.6 & 9.8 & \\
\hline Cost to export (US\$ per container) & 4,867 & 1,660 & 905 & \\
\hline Documents for import (number) & 9.0 & 9.0 & 5.0 & \\
\hline Time for import (days) & 102.0 & 43.7 & 10.4 & \\
\hline Cost to import (US\$ per container) & 5,520 & 1,986 & 986 & \\
\hline \multicolumn{5}{|l|}{ Enforcing Contracts } \\
\hline Procedures (number) & 41.0 & 39.4 & 31.3 & \\
\hline Duration (days) & 743.0 & 643.0 & 443.3 & \\
\hline Cost (\% of claim) & 77.4 & 48.7 & 17.7 & \\
\hline \multicolumn{5}{|l|}{ Closing a Business } \\
\hline Time (years) & - & 3.4 & 1.3 & \\
\hline Cost ( $\%$ of estate) & - & 20.0 & 7.5 & \\
\hline Recovery rate (cents on the dollar) & - & 17.1 & 74.1 & \\
\hline
\end{tabular}


35. Basic infrastructure and public services, the DTIS finds, are inadequate. Fewer than 2-3 percent of the population has access to electricity. The state electricity company (STEE, Societe Tchadienne de l'Eau et de l'Electricite) in theory has a capacity of 38 megawatts but produces only 20 - barely enough to power the pumps of the public water system and a few large buildings in the capital. Well-to-do households and all enterprises produce their own electricity at high cost using imported diesel. The roads are in such bad shape that trucks in Chad wear out at an accelerated pace, and access to the communications infrastructure is well below the regional average.

36. The climate for doing business is poor. The quality of governance poses problems at all levels of government. Businesses complain about fiscal harassment, competition from smuggled imports (e.g., sugar); state interference (e.g. telecommunications); and government agencies playing favorites. The business climate suffers from

distortions that raise the cost of production (lack of access to financing, improper taxation, inadequate roads and communications, excessive bureaucracy, predatory behavior by civil servants, corruption, and rent-seeking); and

heightened risk (poor protection of property rights, poor functioning of titling system, an ineffective court system, and a bad system for enforcing contracts).

37. A number of serious barriers to Chad's external trade lie beyond its borders and are thus essentially outside its control. A major distortion on the global market holds back the cotton sector: large subsidies to cotton growers in developed countries depress prices to cotton growers in developing countries. Furthermore, it will be difficult for Chad to take advantage of the growing international commerce in food and agricultural products because compliance with sanitary and phytosanitary norms is far in the future. And being landlocked, Chad is particularly sensitive to the costs of overland transportation. Lack of cooperation with the administrations in Cameroon and Nigeria is part of the problem. The main transit corridor is from Douala in Cameroon to N'djamena. Customs operations in Douala are slow, as are those at the border crossing into Chad. The export of livestock into Nigeria is equally affected by delays at customs.

38. But Chad also experiences trade barriers at its borders that are in principle amenable to government reform. The DTIS concludes that customs administration is highly ineffective. It does not respect international norms, makes very limited use of information technology, grants exemptions on an ad hoc basis, exacts irregular payments, permits contraband, rarely observes elementary rules, and insists on time-consuming formalities for exports. Reform of the customs administration is urgent. Tariffs and duties themselves are not so high as to be a major obstacle to trade but efforts to reduce, simplify, and improve them would nonetheless be helpful. 
39. The DTIS assessment is reflected in the government's latest Poverty Reduction Strategy Paper (PRSP), adopted in March 2008. ${ }^{11}$ The section describing the five axes of the government's growth strategy describes how some of those challenges are being addressed. With respect to governance, the government places a high priority on maintaining the political dialogue, consolidating peace, and improving security all around. ${ }^{12}$ Better governance in economic policy is being pursued through a strategy of enhanced transparency of all government operations and functions, notably budget execution and procurement. The government commits to reforming Cotontchad and thereby improving the prospects of the cotton sector. It also reaffirms its plans for improving and enlarging the supply of electricity by reforming the STEE, building a topping plant to produce diesel for electricity generation, constructing a refinery plus power plant, and connecting Chad to Cameroon's electricity grid. Finally, the PRSP outlines the government's ambitious plan for having $1,546 \mathrm{~km}$ of asphalt roads by 2011 (the network grew from $346 \mathrm{~km}$. in 2000 to $669 \mathrm{~km}$. in 2005 and to 1,021 km in 2006).

\section{Conclusions}

40. Dominated by developments in the oil sector, Chad's balance of payments is vulnerable to the indirect effects of the sector's volatility. The country's ample reserves are insulated from oil sector shocks to the extent that oil-sector-related flows for trade in goods and service, factor income and capital automatically offset each other. However, an inadequate fiscal policy response to declining oil revenue would put the reserves at risk. Economic diversification is the answer both to the short-run problem of oil sector volatility and the long-term challenge presented by gradual depletion of current oil resources.

41. The conclusion of the analysis using the CGER methodologies is that Chad's REER is not out of line with fundamentals and is consistent with external stability. However, the limitations of the data are significant. The equilibrium real exchange rate approach found no robust relation between the REER and the fundamentals. The macroeconomic balance approach shows an overvaluation of $3 \frac{1}{2}$ percent and the external sustainability approach an overvaluation of $2 \frac{1}{4}$ percent.

\footnotetext{
${ }^{11}$ See Document de Strategie de Croissance et de Reduction de la Pauvrete, Republique du Tchad, Mars 2008.

${ }^{12}$ For a recent assessment of political governance, see Chad: A New Conflict Resolution Framework, International Crisis Group, Africa Report No. 144, 24 September 2008 at http://www.crisisgroup.org/home/index.cfm?id=5694\&l=1
} 
42. Inadequate human and physical infrastructure and the poor quality of Chad's governance places private producers at a serious disadvantage when competing in the international marketplace. These factors, which are amenable to government reform, are compounded by factors outside government control, notably the country's landlocked location. In its March 2008 PRSP the government acknowledges the serious problems afflicting its internal and external trade and lays out a medium-term strategy for addressing them. Chad's current substantial oil revenues - the recent price decline notwithstandingpresent a historic opportunity for implementing it. 
22

Appendix I

Figure 3. Chad. REER and Equilibrium REER

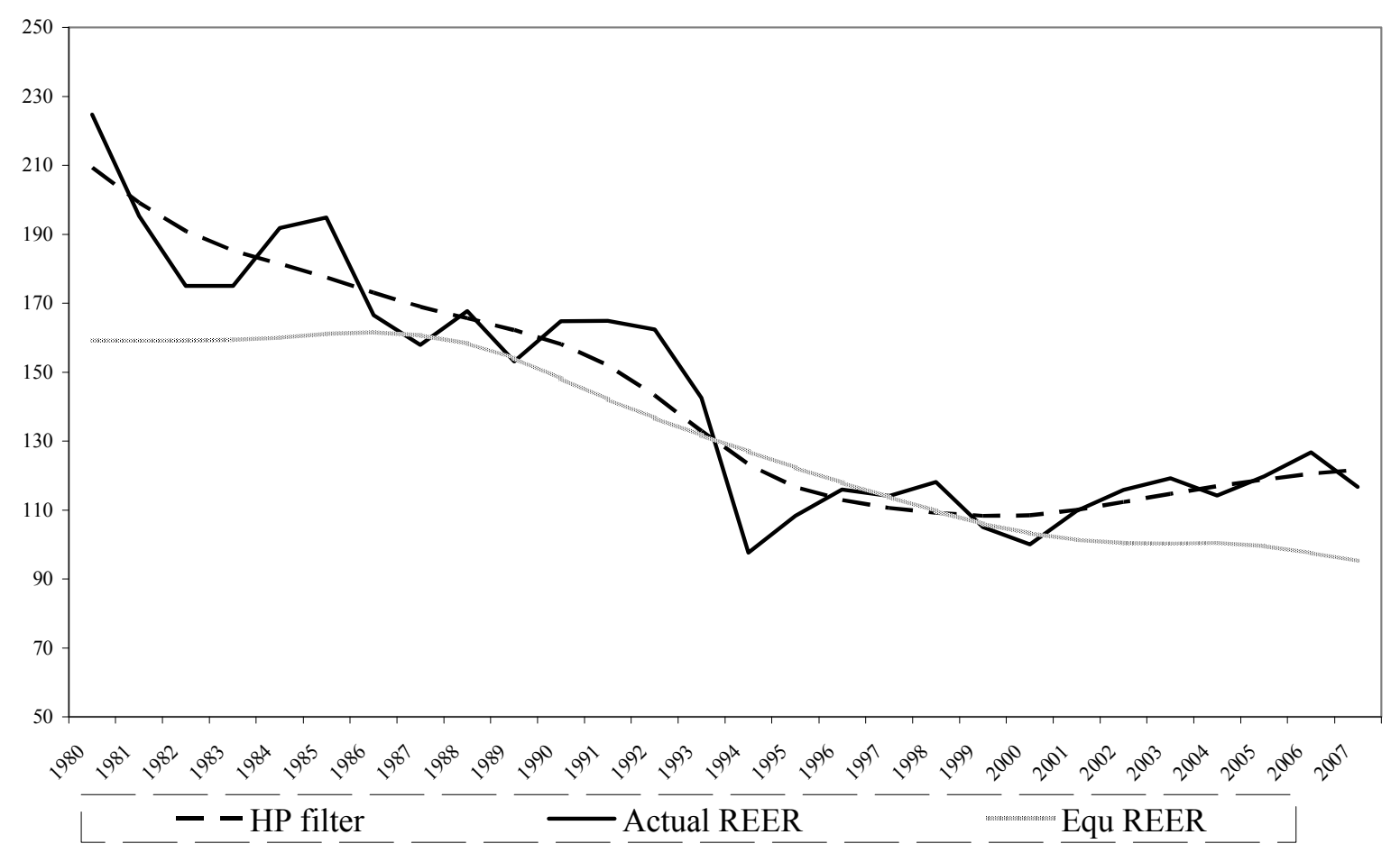

Figure 4. Chad: REER and Equilibrium REER

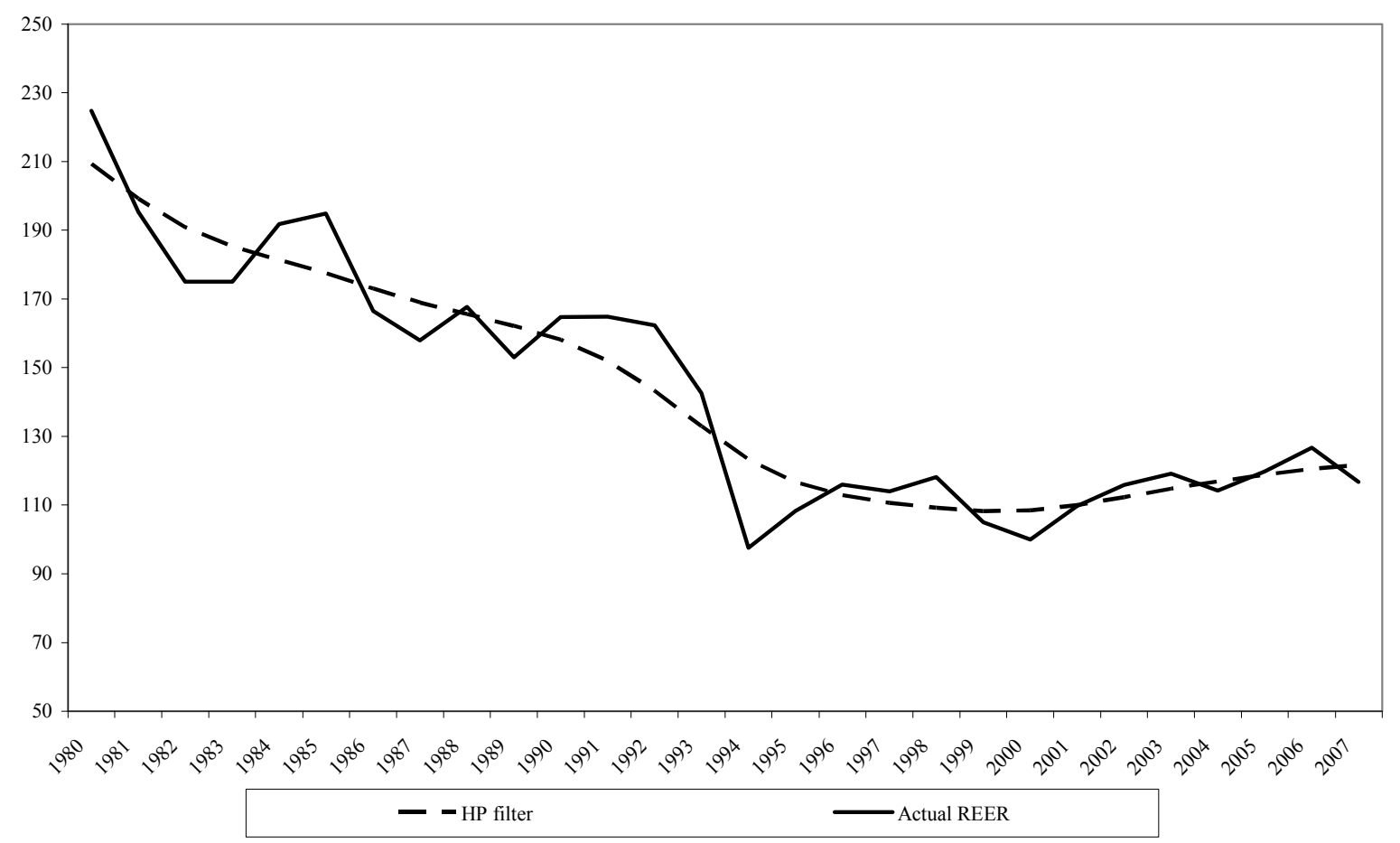

C International Monetary Fund. Not for Redistribution 


\section{References}

International Monetary Fund, 2008, "Methodology for CGER Exchange Rate Assessments," (Washington: International Monetary Fund),

, 2008, CEMAC_-Selected Issues and Statistical Appendix (www.imf.org), (Washington: International Monetary Fund).

,2008, Niger_-Selected Issues and Statistical Appendix (www.imf.org), (Washington: International Monetary Fund).

, 2008, WAEMU—Selected Issues (www.imf.org), (Washington: International Monetary Fund).

Stephanie Levy, Overseas Development Institute, London (2007), "Public Investment to Reverse Dutch Disease: The Case of Chad", Journal of African Economies, Volume 16, Number 3, pp. 439-484. 


\section{ChAPTER II}

\section{An Assessment of Fiscal Sustainability For Chad}

\section{INTRODUCTION}

43. The pursuit of sustainable fiscal policies is critical for oil exporters. The costs of failing to pursue sustainable fiscal policies in oil exporting countries has been dramatically illustrated in the past by the boom-bust cycles of the 1970s and 80s. In those episodes, countries that had excessively expanded their spending and borrowed on the back of high oil revenues had to abruptly adjust their fiscal policy when oil prices declined sharply and debt repayments came due. This sharp fiscal adjustment led to severe negative consequences for growth. In this regard, an assessment of fiscal sustainability is an important element of the surveillance agenda for an oil exporter such as Chad, particularly given limited oil wealth and highly volatile oil prices, as illustrated by recent experience.

\section{Chad is a new oil producer with relatively small proven reserves and high} extraction rates. Chad started to produce and export oil from its one producing region in 2003, with revenues commencing fully in 2004. Proven reserves are estimated at about 600 million barrels and are expected to be depleted by 2032. In this regard, Chad's oil production is currently smaller than most other African oil exporters. Extraction rates in Chad, proxied by production as a share of reserves, are about 8 percent, which is high compared with other region producers.

\section{Chad is confronted with key policy challenges that are well known to countries} abundant in natural resources. Key challenges include (i) managing volatile and unpredictable oil revenue flows to prevent pronounced fluctuations in economic activity and the real exchange rate: (ii) addressing the exhaustible nature of oil resources with prudent intertemporal decisions on consumption and saving, and (iii) ensuring a high return to public spending, through consistency with absorptive capacity and a sustainable fiscal deficit. In this regard, oil producers have often succumbed to strong political economy pressures for large government spending increases during periods of positive terms of trade shocks, which prove difficult to reverse when oil prices are less favorable or production declines.

\section{This paper examines how Chad has fared on these challenges by providing an} assessment of fiscal sustainability and progress on the policies to ensure such sustainability. The paper has three sections. In the first section, fiscal policy in Chad in recent years is compared with that in 28 other oil producing countries, including in a historical perspective of the boom-bust cycles of the 1970s that culminated in the debt crisis of the 1980s. In the second, section the paper goes beyond relative comparisons with other oil countries, and provides and assessment of whether fiscal policy (measured by the non-oil primary deficit (NOPD)) is sustainable under various permanent income hypothesis type 
approaches. A final section concludes and discusses briefly reforms to ensure fiscal sustainability in Chad.

\section{Fiscal Developments Over the Oil ERA}

\section{Fiscal policy has been expansionary since the onset of oil production (Figure 1).}

The NOPD has deteriorated from about 3 percent of non-oil GDP in 2003 to about 22 percent of non-oil GDP on a commitment basis in $2007 .{ }^{13}$ Given an improvement in the level of nonoil revenues from about 9 percent of non-oil GDP in 2003 to 11 percent of non-oil GDP in $2007,{ }^{14}$ the deterioration in the NOPD is mainly accounted for by an increase in domestically financed primary spending of about 20 percentage points of non-oil GDP. The large increase in oil revenues of over 27 percent of non-oil GDP in the same period financed this large increase in domestic primary spending in spite of a significant reduction in foreign financing of 7 percentage points of non-oil GDP.

\section{A large expansion in primary current spending and domestically financed} capital spending were mainly responsible for the fiscal expansion. Primary current spending increased by about 14 percentage points of non-oil GDP, while domestically financed capital spending increased by about 6 percentage points in the period 2003-2007. Higher security spending in the form of increases in the number of military personnel, increases in goods and services to support a larger troop contingent, and in exceptional security spending, ${ }^{15}$ accounted for about 56 percent of the overall increase in primary current spending during 2003-07 (Figure 2). The remainder of the overall increase derives mainly from increased transfers to finance losses of the state cotton and energy companies (Cottonchad and STEE respectively) and a major increase in the civil service wage bill. The latter accounted for 55 percent of the overall increase in the wage bill and 29 percent of the total increase in the number of public sector workers during 2003-2007.

\footnotetext{
${ }^{13}$ The NOPD is defined consistently with the staff report as total revenue excluding grants, oil revenue and interest on government assets, minus total expenditure excluding interest payments and foreign financed investment. Following Barnett and Ossowski (2003), this paper focuses on the NOPD rather than the overall balance because it eliminates fluctuations due to reasons unrelated to the fiscal stance and fiscal sustainability (such as volatile oil prices) and makes clear that fiscal proceeds from oil should be viewed as financing. Recent movements in the overall balance which switched from a deficit of about 16 percent non oil GDP in 2003 to a surplus of about 2 percent in 2007 mainly due to higher oil prices and production illustrates this point clearly.

${ }^{14}$ Non-oil revenues remained roughly at their historical levels between 8 and 9 percent of non-oil GDP until 2006. The increase occurred mainly in 2007 reflecting buoyancy in income taxes related to significant wage increases, the collection of income tax arrears from previous years, and improved collection from property taxes.

${ }^{15}$ Exceptional security spending captures military spending generally not expected at the time of the budget spent in response to unexpected security threats and includes purchases of military equipment.
} 
Figure 1. Evolution of Selected Fiscal Aggregates-2003-2008 (Proj.)
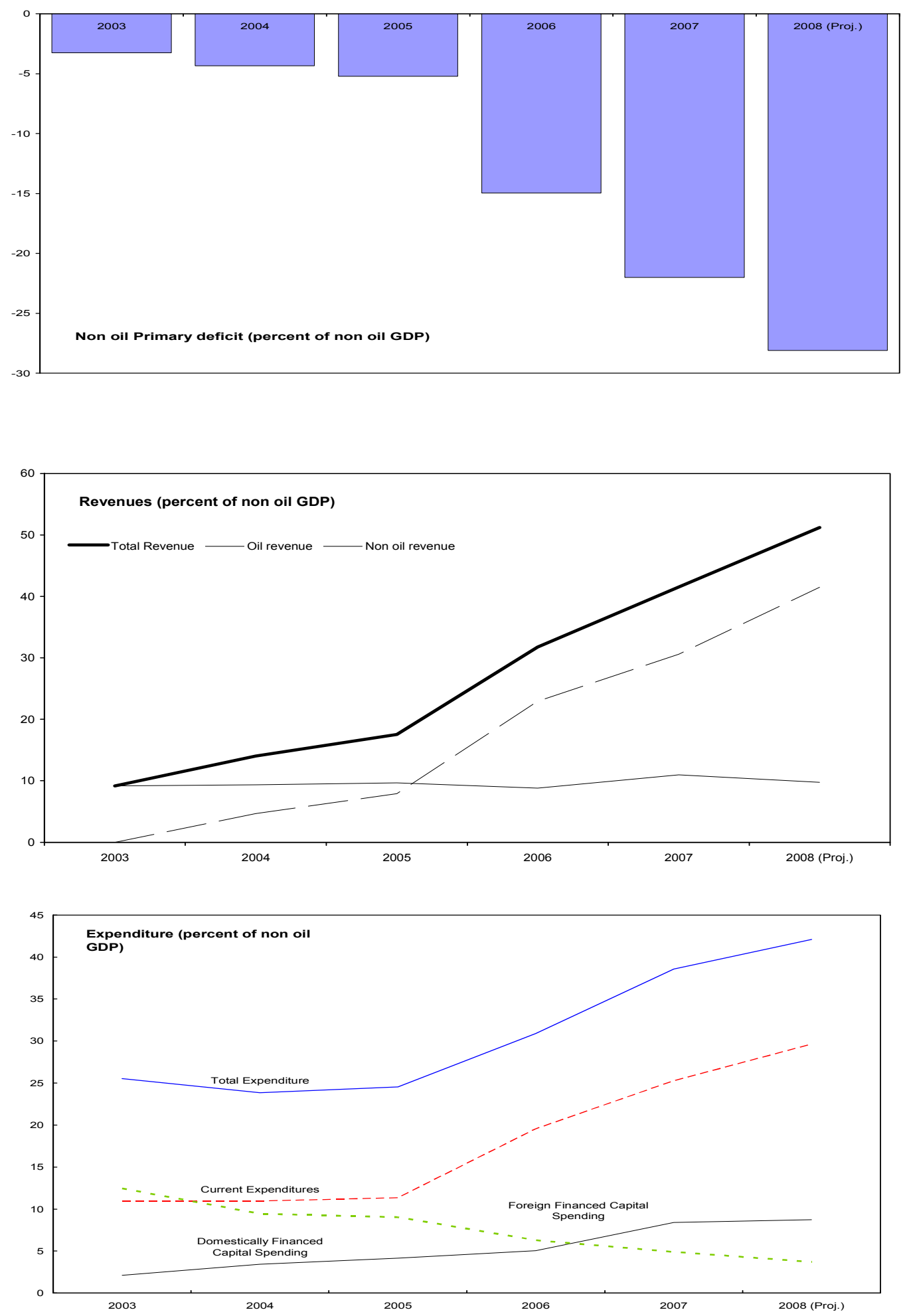

Source: Chadian Authorities and Fund Staff Estimates 
Figure 2. Evolution of main components of Primary Current Spending-2003-2008 (Proj.)

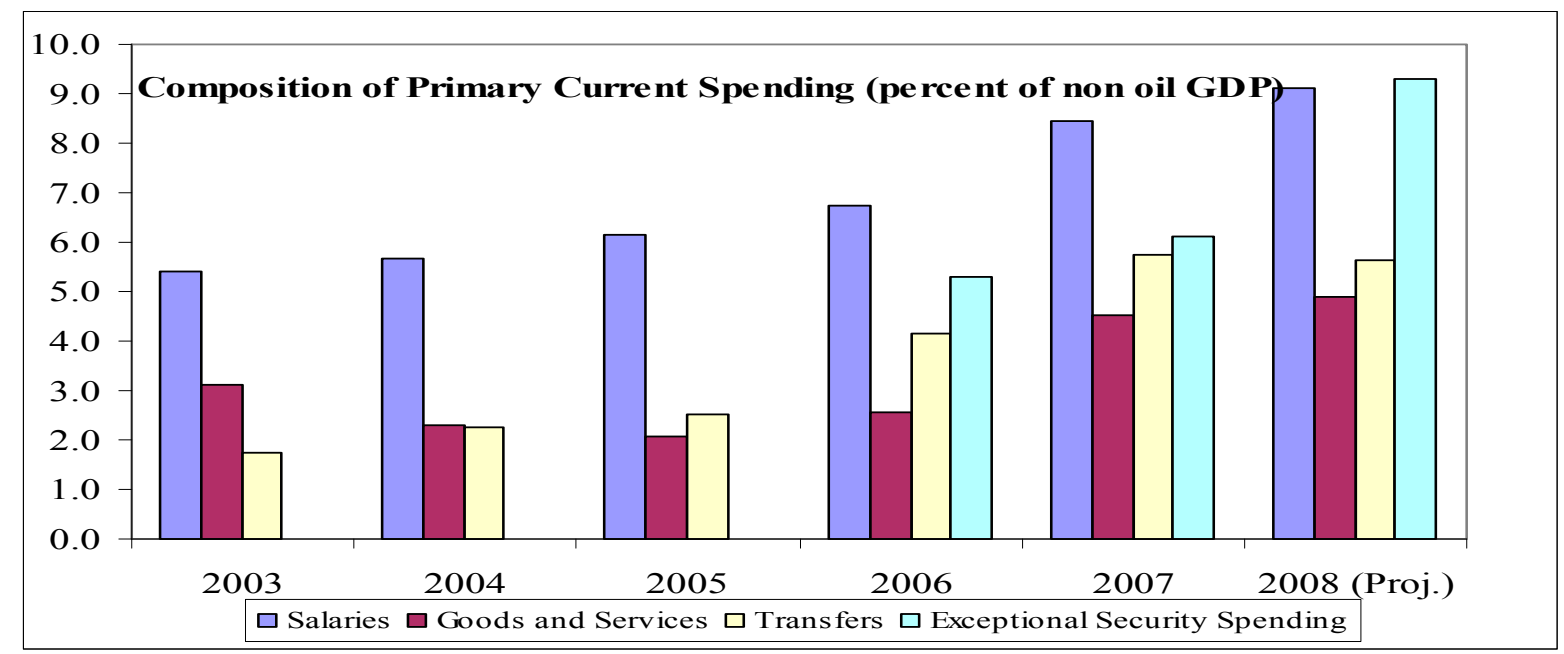

Source: Chadian Authorities and Fund Staff Estimates.

\section{Primary current spending and the wage bill have significantly increased as a}

share of non-oil revenues. Primary current spending as a share of non-oil revenues has risen from the already worrisome level of 112 percent in 2003 to a level of 224 percent in 2007. In particular, the wage bill as a share of non-oil revenues has increased from about 60 percent in 2003 to 80 percent in 2007 . These ratios highlight a clear vulnerability to sustaining current spending levels if oil revenues were to decline significantly.

50. Public debt has fallen as a share of non-oil GDP. The significant improvement in the overall balance generated by the oil revenue increase (Figure 3 ) led to a significant reduction in financing needs. Combined with the continuous servicing of debt and the decline in foreign financing as a share of non-oil GDP observed during 2003 and 2007, this led the nominal external debt to grow less than 10 percent in nominal terms, from CFAF 736 billion in 2003 (54 percent of non-oil GDP) to CFAF 794 billion in 2007 (43 percent of non-oil GDP). A gradual repayment of domestic debt including arrears also contributed to the decline in domestic debt, which fell from 142 billion in 2005 (9 percent of non-oil GDP) to 99 billion in 2007 (5 percent of non-oil GDP). ${ }^{16}$

\footnotetext{
${ }^{16}$ Reliable and comprehensive domestic debt information prior to the 2005 Mazars report is not available. Debt ratios as a share of GDP are as follows: 46 percent of GDP in 2003 and 24 percent in 2007 for external debt, 5 percent of GDP in 2005 and 3 percent of GDP in 2007.
} 
Figure 3. Evolution of the Overall Balance ${ }^{17} 2003-2008$ (Proj.)

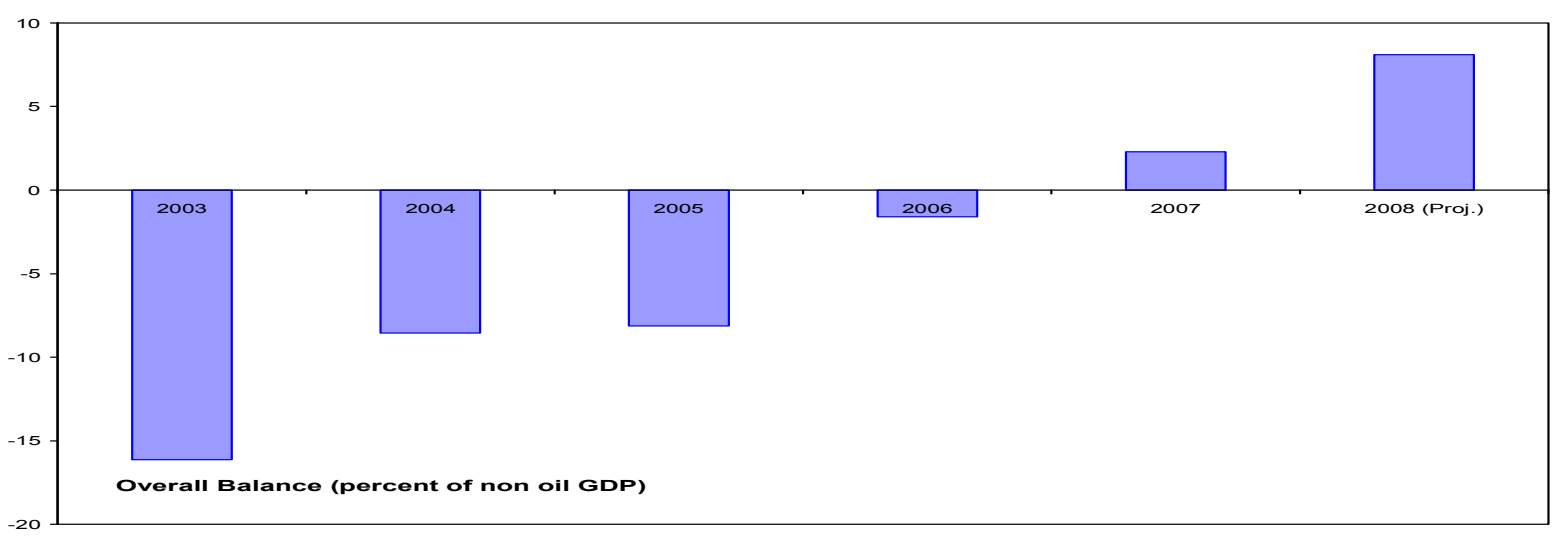

Source: Chadian Authorities and Fund Staff Estimates.

51. These trends in fiscal indicators have been broadly maintained in 2008. The NOPD is expected to have reached 28 percent of non-oil GDP mostly due to further increases in primary current spending driven by higher security spending. The February 2008 attacks on the capital and the desire to preempt further attacks led to additional troop hiring, wage increases for the military, and additional exceptional security spending (mainly military equipment purchases) of 6 percentage points of non-oil GDP in additional current spending. These developments resulted in a further increases in primary current spending and the wage bill as a share of non-oil revenues to 297 percent and 94 percent, respectively. The overall balance is expected to have further improved to about 8 percentage points of non-oil GDP, and external and domestic debt levels reduced further to 37 percent of non-oil GDP and 3 percent of non-oil GDP, respectively.

\section{Chad has spent more of the increase in oil revenues it experienced than most oil} producers in the recent oil price boom. Following Ossowski et. al. (2008), Figure 4 below graphs the ratio of the cumulative change in the non-oil primary balances against the cumulative increase in oil revenues as a share of GDP during the period 2000-2006. ${ }^{18}$ Up to 2006, Chad had spent about 70 percent of the total accumulated oil revenues earned between 2000 and 2006. This is more than most oil producers in the region with the exception of

\footnotetext{
17 The definition of the overall balance data presented above excludes grants and is on a cash basis consistent with the staff report presentation.

${ }^{18}$ Since execution data was not available for part of the sample for 2007, data until year 2006 is used to maximize the size of the sample. Year 2000 is the year when oil prices started their escalation and is therefore used as the beginning year of the oil boom.
} 
Sudan. With respect to the sample of other 28 oil producing countries, only 7 countries spent more than Chad during the 2000-2006 period. ${ }^{19}$

53. Weaknesses in public financial management (PFM) have exacerbated problems in budget control and spending. Main weaknesses are: (i) abuses of exceptional and extrabudgetary spending procedures; (ii) lengthy and poorly-enforced public procurement processes combined with redundant and ineffective controls encouraging the use of noncompetitive bidding and the circumvention of the budget legal framework;

(iii) deficiencies in the budget classification; (iv) deficiencies in planning, budgeting and monitoring of multiyear investment projects; (v) poor cash management, lack of effective commitment controls, and earmarking-based fragmentation of budget procedures; and (vi) insufficient fiscal transparency.

Figure 4. Utilization of Oil Revenues by Oil Producing Countries 2000-2006

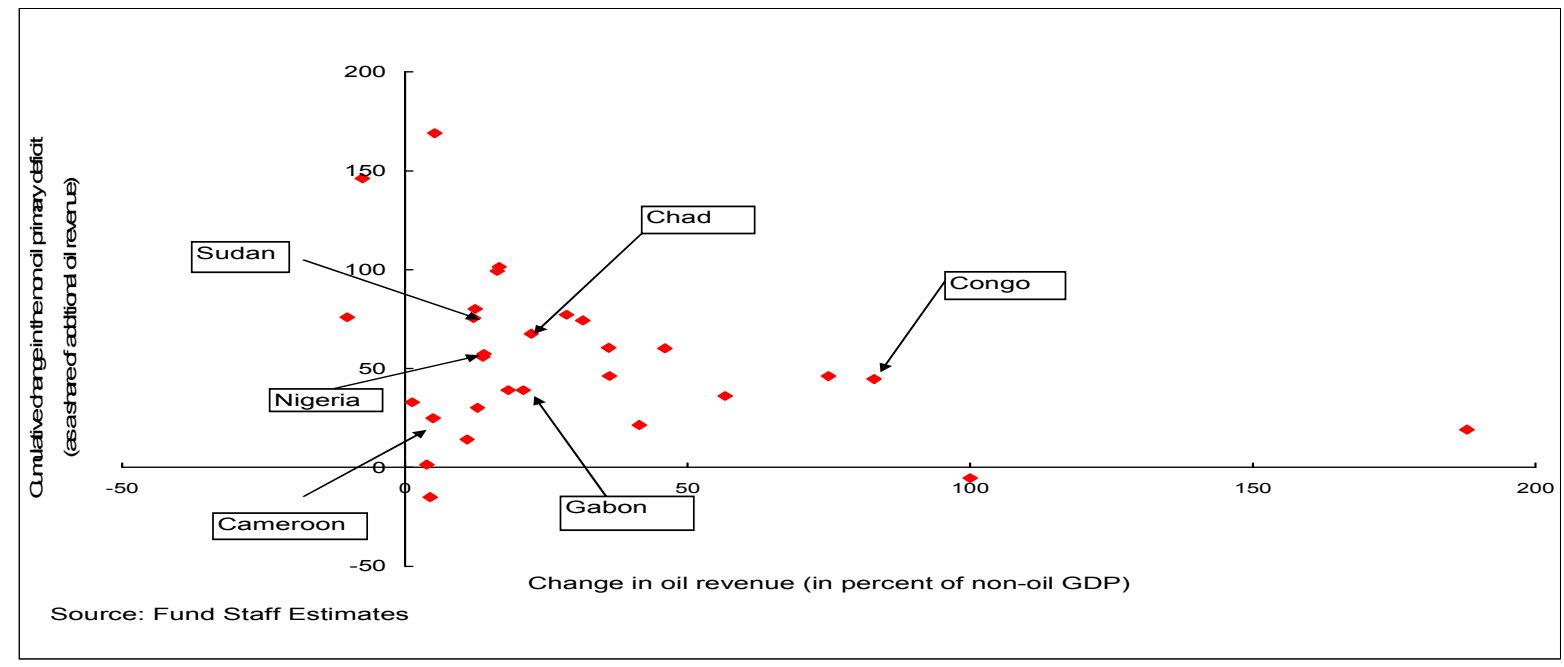

54. The behavior of Chad's major fiscal aggregates in the light of international experience raises questions about fiscal sustainability. The evolution of Chad's fiscal aggregates during the recent high oil price period exhibits important similarities with countries that were forced to undertake costly fiscal adjustment during the $1970 \mathrm{~s} / 80 \mathrm{~s}$ boombust cycle. In addition to a large expansion of the non-oil primary deficit and spending, several of these countries experienced a growing wage bill (such as in the Republic of Congo, Trinidad and Tobago), a rapidly growing investment budget with questionable rates of return on many projects and over the availability of recurrent spending allocations to ensure infrastructure was maintained (such as in the Republic of Congo, Gabon, Nigeria,

\footnotetext{
${ }^{19}$ The sample includes the following 28 oil producing countries: Algeria, Angola, Azerbaijan, Bahrain, Brunei, Cameroon, Congo, Ecuador, Gabon, Indonesia, Iran, Kazakhstan, Kuwait, Mexico, Nigeria, Norway, Oman, Qatar, Russia, Saudi Arabia, Sudan, Syria, Timor Leste, Trinidad and Tobago, United Arab Emirates, Venezuela, Vietnam, and Yemen.
} 
Trinidad Tobago), and increasing subsidies to inefficient sectors (see Gylfanson (2001) for examples and discussion). ${ }^{20}$ One exception is Chad's relatively low public debt ratios, which in part reflect the lack of lending opportunities during decades of civil war, but also some degree of prudent debt management.

\section{Assessing Sustainability and the Sustainable Non-Oil Primary Balance}

\section{A variety of approaches have been discussed to formulate sustainable medium-} term fiscal policy in oil producing countries. Sustainable fiscal policy is defined as one where the intertemporal budget constraint of the government (i.e. the present value of government spending needs to be less or equal to the present value of non-oil revenues plus net government assets ${ }^{21}$ ) is satisfied in the long term while meeting financing constraints in the short term. As highlighted in Katz et al. (2004), most approaches entail guiding fiscal policy with explicit (i.e. when enforced by law) or implicit rules such as for example a "bird in hand" or balanced budget approach. A "bird in hand" policy is one that is sustainable by definition, since it consists of only spending the interest earned on existing financial assets resulting from oil savings. A balanced budget rule is also typically considered sustainable since it involves adjusting spending to the level of revenues. ${ }^{22}$ These rules are sometimes viewed as extremes since the first implies saving a large fraction of oil revenue, while the second implies spending all oil revenue as it materializes.

\section{The permanent income hypothesis (PIH) approach is an important method to} derive rules to guide medium-term fiscal policy. It's importance derives from it providing rules which address key fiscal policy challenges facing oil producers. By linking government consumption to oil wealth rather than current oil revenues, it provides rules to guide fiscal policy that largely delink government consumption from short-term fluctuations in oil prices, thereby smoothing the government's consumption path. A more stable consumption path helps address the concern of fiscal policy exacerbating the volatility of economic activity and the real exchange rate generated by oil price fluctuations, and reduces the risks of exceeding absorptive capacity constraints that accompany rapid increases in spending. Finally, it allows incorporation of different welfare criteria with relative ease through welfare functions. The PIH approach requires a chosen welfare function to be maximized subject to

\footnotetext{
${ }^{20}$ See the following papers for a more detailed discussion of the developments in the mentioned countries: Carcillo et. al. (2007) for the Republic of Congo, Leigh and Olters (2006) for Gabon, Irineu de Carvalho Filho (2005) for Trinidad and Tobago and Sala-i-Martin and Subramanian (2003) for Nigeria.

${ }^{21}$ Net assets of the government includes oil wealth, or the present discounted value of future net oil revenues.

${ }^{22}$ Note however that this is strictly true if a country is not a net debtor and the horizon is not finite. If the horizon is finite and a country starts applying the rule as a net debtor, a balanced budget rule would not satisfy the intertemporal budget constraint since at some point surpluses would need to be run to pay down the debt principal.
} 
the intertemporal budget constraint to derive fiscal policy rules. Since PIH derived fiscal policy rules emerge from a welfare maximization, the PIH approach adds a sense of optimality to the sustainability concept allowing to discriminate among rules which imply sustainable paths. ${ }^{23}$

\section{The PIH approach has been applied to several oil producing countries. This} includes countries facing similar challenges to Chad, such as Congo, Cameroon and Gabon. ${ }^{24}$ This is because, in addition to the advantages discussed above, medium-term fiscal frameworks guided by PIH are flexible in accommodating country-specific circumstances. Convergence to a sustainable NOPD may be achieved by front-loaded fiscal adjustment (such as in one period adjustment models as in Barnett and Ossowski (2003)) or more gradually to minimize adjustment costs or allow for habit persistence (such as in Leigh and Olters (2006) or Carcillo et al. (2007)). Also, a low income country could opt for gradualism permitting higher levels of investment spending early on (as discussed in Takizawa et al. (2004)). However, unless that investment is productive not only in terms of a social rate of return but also in terms of future revenues, the delayed adjustment implies a lower sustainable NOPD. PIH approaches can also easily allow the assumption of oil wealth being consumed over a relatively long but finite time period to capture political economy considerations (as suggested in Clausen (2007)).

\section{This section provides estimates of sustainable long-term NOPD that would result} if some of these approaches were applied to Chad. Four different types of rules were simulated: a bird in hand rule, a balanced budget rule, and two types of rules derived from the PIH approach. ${ }^{25}$ The first PIH derived rule is one where a flat government consumption annuity as a share of non-oil GDP is computed on the basis of an estimate of oil wealth and a

\footnotetext{
${ }^{23}$ For example, it is clear that a balanced budget rule would not be supported by the permanent income approach since it would imply large procyclical responses of government spending to changes in oil prices which would not be optimal under standard welfare functions.

${ }^{24}$ There are many other oil and natural resource rich countries more generally for which the permanent income hypothesis approach has been applied. These include for example: Sao Tome and Principe (Segura (2006)), Botswana (Basdevant (2006), Clausen (2007)), Russia (Balassone, Takizawa and Zegrebs (2006)), Nigeria (Baunsgaard (2003)), Trinidad and Tobago (Irineu de Carvalho Filho (2006))

${ }^{25}$ Only these four rules are discussed in the main text. However, estimates were also prepared for four other rules which are derived from traditional one-period adjustment PIH approaches a la Barnett and Ossowski (2003). They differ from the PIH rules in the text mainly in terms of the underlying welfare function, which leads to different measures of government consumption being kept constant over time, i.e. real aggregate consumption and real per capita consumption. For each of these two other measures, the NOPDs are computed for versions where wealth is consumed in an infinite or in a finite but long period of time (63 years). The results for these rules are presented in the Appendix Tables 1 and 2.
} 
finite number of years in which oil wealth would be consumed (further discussion below). ${ }^{26}$ The long-run sustainable NOPD is then computed by subtracting from an assumed level of non-oil revenues the level of primary spending which is a function of the annuity and an assumed level of non-oil revenues. Adjustment to a long-term NOPD is front loaded with this rule, since government consumption would need to adjust in one period to the long term sustainable level. The second PIH derived rule is more realistic, and entails adjustment to a sustainable long-term NOPD gradually in the context of an infinite horizon model (Carcillo et al. (2007). In the latter, government primary consumption evolves according to a weighted average of (i) the level of government primary consumption that could be financed by wealth $^{27}$ if adjustment were done in one period (i.e. no habit persistence) and (ii) the level of government primary consumption in the previous period (see Appendix for the precise formula). A steady state level of government primary consumption is achieved after a certain number of years depending on how fast the adjustment takes place. The non-oil primary balance path is then computed by subtracting from a non-oil revenue assumption the government primary consumption level. The weights in the government primary consumption formula depend on how important habit persistence or adjustment costs are assumed to be. The higher the habit persistence/adjustment costs coefficient assumed, the more gradual the adjustment is. This comes at the expense of a lower long term sustainable NOPD given that the model does not assume productive government investment. ${ }^{28}$

\section{The annuity calculation is a key part underlying the estimates of government consumption for most PIH rules presented in the paper. ${ }^{29}$ The annuity refers to an} implied stream of payments over a specified period of time which can be finite or infinite (proxying for very long time periods). The annuity is used to transform a projected stream of oil

\footnotetext{
${ }^{26}$ The finite number of years assumed in the calculation is 63 years. See Clausen (2007) for additional discussion.

${ }^{27}$ The definition of wealth in the model includes oil wealth, net financial assets and the present value of non-oil revenues.

${ }^{28}$ See Carcillo et al. (2007) for a detailed derivation of the weighted average formula for the government primary consumption which is also shown in the appendix to illustrate the nature of the calculations. The assumption that there is no productive investment by the government is a limitation of the model but it still provides a useful benchmark since it is consistent with the limited evidence showing any significant relationship between public investment and growth.

${ }^{29}$ The annuity calculation was carried out for all PIH rules estimates included in this paper, with the exception of Carcillo et al. (2007) where the calculations for government consumption are more complicated and follow the formula included in the appendix.
} 
revenues into a hypothetical government consumption annuity with the same present value. Therefore, the calculation is done in three steps (i) calculate present value of the oil revenue stream under the assumption of a certain interest rate for each year; (ii) set the total present value of oil revenue equal to the total present value of the hypothetical government consumption annuity; and (iii) express the government consumption annuity relative to a certain denominator. ${ }^{30}$ Figure 5 illustrates the case of a government consumption annuity which is constant as a share of non oil GDP.

Figure 5. Oil Revenue, Annuity, and Asset Accumulation (Constant Government Consumption Annuity as a Share of Non Oil GDP)

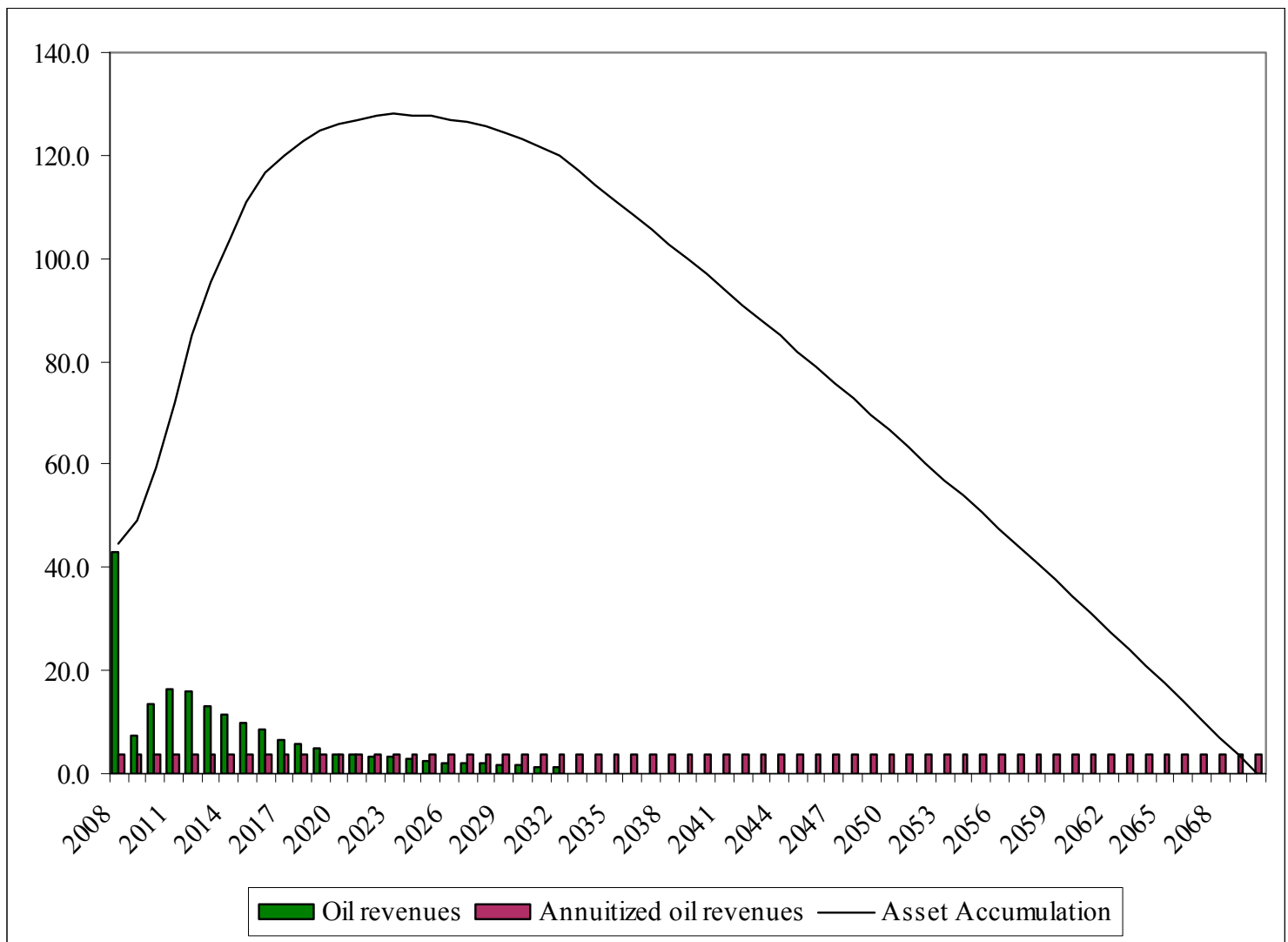

\footnotetext{
${ }^{30}$ The annuity on oil wealth can be calculated in several ways depending on the rule. One is to calculate a government consumption annuity which is constant as a share of non-oil GDP as in the first PIH rule discussed in the text. Other alternatives are government consumption annuities which are constant in real terms or constant in real per capita terms for a finite period of time or for an infinite time period. These alternatives are the ones used to compute the results for the other PIH rules which are presented in the appendix.
} 


\section{The main oil sector and macroeconomic assumptions that entered the baseline calculation of NOPDs are broadly consistent with the baseline scenario of the staff report and DSA (Table 1). ${ }^{31}$}

Table 1- Main Macroeconomic, Oil Sector, and Habit Persistence Parameter Assumptions

\begin{tabular}{|c|c|c|c|c|c|}
\hline & $\begin{array}{l}2009-2012 \\
\text { Average }\end{array}$ & $\begin{array}{l}\text { 2013-2016 } \\
\text { Average }\end{array}$ & $\begin{array}{l}2017-2020 \\
\text { Average }\end{array}$ & $\begin{array}{l}\text { 2021-2045 } \\
\text { Average }\end{array}$ & $\begin{array}{r}\text { 2046-2070 } \\
\text { Average }\end{array}$ \\
\hline \multicolumn{6}{|l|}{ Oil Sector Assumptions } \\
\hline Reference oil price (dollars per barrel) 1/ & 66.3 & 79.6 & 86.6 & 101.4 & -- \\
\hline Oil Production (millions of barrels) $1 /$ & 45.0 & 35.4 & 20.3 & 12.0 & .- \\
\hline $\begin{array}{l}\text { Tax take (net oil revenues as a share of oil sales valued at the } \\
\text { Doba after well price) } 1 /\end{array}$ & 35 & 36 & 36 & 36 & -- \\
\hline \multicolumn{6}{|l|}{ Macroeconomic Variables } \\
\hline Real Non Oil GDP growth (in percent) & 4.7 & 4.4 & 4.1 & 3.2 & 3.0 \\
\hline Real Interest Rate (in percent) & 4.0 & 4.0 & 4.0 & 4.0 & 4.0 \\
\hline Non oil revenues (in percent of non oil GDP) & 10.0 & 11.1 & 12.2 & 16.4 & 17.5 \\
\hline \multicolumn{6}{|l|}{ Other Parameters } \\
\hline $\begin{array}{l}\text { Habit persistence coefficient assumption for the } \\
\text { estimation using the Carcillo et al. (2007) model }\end{array}$ & 0.6 & 0.6 & 0.6 & 0.6 & 0.6 \\
\hline
\end{tabular}

Source: Fund Staff Estimates

1/ 2021-2045 shows only the average until 2032, the expected last year of production.

\section{Results suggest that Chad's current NOPD levels exceed sustainable levels by a}

large margin (Table 2). The results in the table below suggests that for all the approaches estimated the long run sustainable NOPD ranges from a small surplus to low single digit deficits. ${ }^{32}$ The results for the PIH approach derived rules also illustrate the cost of gradualism in fiscal adjustment, since following a more gradual approach results in a lower sustainable long run NOPD. The key result is that irrespective of the approach, these NOPD levels are far smaller than Chad's expected NOPD in 2008, which is projected to be about 28 percent of non-oil GDP.

\footnotetext{
${ }^{31}$ All macroeconomic variables and oil sector variables determining the level of oil revenues are the same as in the baseline scenario, with the exception of the non-oil real GDP growth rate and the real interest rate. For the purpose of the estimations of the long-term NOPDs, the assumptions for the latter variables had to be adjusted to avoid a situation where the real interest rate is permanently below the real non-oil GDP growth rate, as this would trivially solve any sustainability problem. To address this problem and avoid forcing an assumption of an unrealistically high real interest rate, the real non-oil growth rate after 2012 is gradually adjusted for it to converge to a long term level of 3 percent by 2032 assuming that there is a long catching-up period in which growth rates will remain above this lower long term rate. The real interest rate is assumed to be flat at 4 percent during the whole period, a level consistent with the assumption in Carcillo et al. (2007) for the Republic of Congo. While in Chad the large majority of public debt and assets earn relatively low real interest rates given concessionality and investment constraints imposed by the BEAC, it would be unrealistic to assume these rate levels for the purpose of this exercise since both features are likely to change in the next 20 to 30 years.
}

${ }^{32}$ This includes the four additional rules discussed in footnote 13. The results are presented in Appendix Table 1. 
Table 2. Average Levels of Non-Oil Primary Deficits Under Different Approaches $2009-2012 \quad 2013-2016 \quad 2017-2020 \quad 2021-2045 \quad 2046-2070$

Bird in Hand

Balanced Budget

PIH: Villafuerte, Leigh and Carcillo (2007) (infinite horizon)

$\mathrm{PIH}$ : Constant government consumption annuity as a share of non oil GDP (finite horizon)
$-1.4$

$-10.1$

$-13.1$

$-1.1$
$-4.4$

$-8.5$

$-8.9$

$-2.3$
$-5.1$

$-3.7$

$-6.5$

$-2.6$
$-2.8$

$-0.1$

$-1.0$

$-2.6$
0.0

0.9

0.4

$-2.6$

Source: Fund Staff Estimates.

62. The results are robust to sensitivity analysis on the parameters of the models including on oil revenues (Table 3). For all the sensitivity tests on the parameters, results imply that the long term NOPDs would remain in the low single digits. ${ }^{33}$ In particular, larger percentage term deviations from the baseline are considered for oil prices and production. This is to illustrate that even if oil prices or production were significantly more favorable than assumed in the baseline (for example due new production or significantly more favorable oil prices), given the current relatively low levels of oil production, long-term NOPDs would remain in the low single digits.

\section{REFORMS TO Restore Fiscal SUSTAINABILITY IN CHAD}

\section{A significant reduction of the NOPD towards sustainable long term levels is} urgently needed in Chad. The rapid growth in the NOPD in recent years to well beyond sustainable levels, high ratios of primary spending and the wage bill as a share of non-oil revenues, and expenditure of a high proportion of oil revenues, are all indicative of the need to adjust. While the difficult security situation contributed to these developments generating large security spending increases, the oil windfall has led to large spending increases across all other categories, including continued financing of loss making state enterprises and other transfer programs, the wage bill, and a very large expansion of domestically financed investment. Beyond fiscal policy, weaknesses in budget control have been an important factor too.

64. The fiscal policies pursued in the recent past and a declining outlook for oil prices confront Chad with a real expenditure rationalization problem. Given that an insufficient cushion of savings was built in the recent high oil price years to preserve expenditures during a period of decline in oil prices, and that spending remains high in relation to non-oil revenue, a significant portion of the adjustment will need to come from expenditure rationalization.

\footnotetext{
${ }^{33}$ This result also holds for the four additional rules mentioned in footnote 13 whose results are discussed in the Appendix. See Appendix Table 2 for details.
} 
Table 3: Sensitivity Analysis of NOPD Estimates

\begin{tabular}{|c|c|c|c|c|c|c|c|c|c|c|}
\hline \multirow[b]{3}{*}{ Baseline Parameters } & \multirow{3}{*}{$\begin{array}{r}\begin{array}{l}2009-2012 \\
\text { Average }\end{array} \\
-1.4\end{array}$} & $\begin{array}{l}\text { 2013-2016 } \\
\text { Average }\end{array}$ & $\begin{array}{l}2017-2020 \\
\text { Average }\end{array}$ & \multicolumn{2}{|l|}{$\begin{array}{l}\text { 2021-204. 2046-2070 } \\
\text { Average Average }\end{array}$} & $\begin{array}{l}2009-2012 \\
\text { Average }\end{array}$ & $\begin{array}{l}\text { 2013-2016 } \\
\text { Average }\end{array}$ & $\begin{array}{l}\text { 2017-2020 } \\
\text { Average }\end{array}$ & $\begin{array}{l}\text { 2021-2045 } \\
\text { Average }\end{array}$ & $\begin{array}{l}\text { 2046-2070 } \\
\text { Average }\end{array}$ \\
\hline & & \multicolumn{2}{|c|}{ Bird in Hand (1) } & & & \multicolumn{3}{|c|}{ Balanced Budget (2) } & & \\
\hline & & -4.4 & -5.1 & -2.8 & 0.0 & -10.1 & -8.5 & -3.7 & -0.1 & 0.9 \\
\hline \multicolumn{11}{|l|}{ Sensitivity Tests } \\
\hline \multicolumn{11}{|l|}{ Oil Reference Price } \\
\hline $\begin{array}{l}\text { Higher Oil prices ( } 30 \text { percent higher } \\
\text { each year than baseline starting in 2009) }\end{array}$ & -2.3 & -7.1 & -8.3 & -5.0 & -0.6 & -19.9 & -14.8 & -6.7 & -0.7 & 0.9 \\
\hline $\begin{array}{l}\text { Lower Oil prices ( } 30 \text { percent lower } \\
\text { each year than baseline starting in 2009) }\end{array}$ & -0.4 & -1.6 & -1.7 & -0.5 & 0.6 & -0.4 & -1.6 & -0.2 & 0.6 & 0.9 \\
\hline \multicolumn{11}{|l|}{ Oil Production } \\
\hline $\begin{array}{l}\text { Higher Oil Production ( } 30 \text { percent higher } \\
\text { each year than baseline starting in 2009) }\end{array}$ & -2.0 & -6.4 & -7.5 & -4.5 & -0.4 & -16.9 & -13.7 & -6.1 & -0.6 & 0.9 \\
\hline $\begin{array}{l}\text { Lower Oil Produciton ( } 30 \text { percent lower } \\
\text { each year than baseline starting in 2009) }\end{array}$ & -0.8 & -2.4 & -2.6 & -1.2 & 0.4 & -3.4 & -3.3 & -1.2 & 0.4 & 0.9 \\
\hline \multicolumn{11}{|l|}{ Tax Take } \\
\hline $\begin{array}{l}\text { Higher Tax Take ( } 10 \text { percent higher } \\
\text { each year than baseline starting 2014) }\end{array}$ & -1.4 & -4.5 & -5.3 & -3.0 & -0.1 & -10.1 & -9.2 & -4.1 & -0.2 & 0.9 \\
\hline $\begin{array}{l}\text { Lower Tax Take ( } 10 \text { percent lower } \\
\text { each year than baseline starting 2014) }\end{array}$ & -1.4 & -4.4 & -4.9 & -2.6 & 0.0 & -10.1 & -7.8 & -3.2 & 0.0 & 0.9 \\
\hline \multicolumn{11}{|l|}{ Non oil Revenues } \\
\hline $\begin{array}{l}\text { Higher Non Oil Revenues ( } 10 \text { percent higher } \\
\text { each year than baseline starting 2009) }\end{array}$ & -1.4 & -4.4 & -5.1 & -2.8 & 0.0 & -10.1 & -8.5 & -3.7 & -0.1 & 0.9 \\
\hline $\begin{array}{l}\text { Higher Non Oil Revenues ( } 10 \text { percent lower } \\
\text { each year than baseline starting 2009) }\end{array}$ & -1.4 & -4.4 & -5.1 & -2.8 & 0.0 & -10.1 & -8.5 & -3.7 & -0.1 & 0.9 \\
\hline \multicolumn{11}{|l|}{ Real Interest Rate } \\
\hline Higher real interest rate ( $=4.5$ percent) & -1.6 & -4.8 & -5.5 & -3.1 & -0.1 & -10.1 & -8.5 & -3.7 & -0.1 & 0.9 \\
\hline Lower real interest rate ( $=3.5$ percent) & -1.1 & -4.0 & -4.6 & -2.6 & 0.1 & -10.1 & -8.5 & -3.6 & -0.1 & 0.9 \\
\hline \multicolumn{11}{|l|}{ Long run real Growth Rate } \\
\hline Higher long run real growth rate ( $=3.5$ percent) & -1.4 & -4.4 & -5.0 & -2.7 & 0.1 & -10.1 & -8.5 & -3.6 & -0.1 & 0.9 \\
\hline Lower long run real growth rate $(=2.5$ percent) & -1.4 & -4.4 & -5.1 & -3.0 & -0.1 & -10.1 & -8.5 & -3.7 & -0.1 & 1.0 \\
\hline
\end{tabular}

Source: Fund Staff Estimates

\begin{tabular}{|c|c|c|c|c|c|c|c|c|c|c|}
\hline \multirow[b]{4}{*}{ Baseline Parameters } & $2009-2012$ & \multirow{2}{*}{$\begin{array}{l}\text { 2013-2016 } \\
\text { Average }\end{array}$} & \multirow{2}{*}{$\begin{array}{l}\text { 2017-2020 } \\
\text { Average }\end{array}$} & \multirow{2}{*}{$\begin{array}{l}\text { 2021-2045 } \\
\text { Average }\end{array}$} & \multirow{2}{*}{$\begin{array}{l}2046-2070 \\
\text { Average }\end{array}$} & 2009-2012 & \multirow{2}{*}{$\begin{array}{l}\text { 2013-2016 } \\
\text { Average }\end{array}$} & \multirow{2}{*}{$\begin{array}{l}\text { 2017-2020 } \\
\text { Average }\end{array}$} & \multirow{2}{*}{$\begin{array}{l}\text { 2021-2045 } \\
\text { Average }\end{array}$} & \multirow{2}{*}{$\begin{array}{l}\text { 2046-2070 } \\
\text { Average }\end{array}$} \\
\hline & Average & & & & & Average & & & & \\
\hline & \multicolumn{5}{|c|}{$\begin{array}{l}\text { Villafuerte, Leigh and Carcillo (2007) } \\
\text { (Infinite Horizon) (3) }\end{array}$} & \multicolumn{5}{|c|}{$\begin{array}{l}\text { Constant government consumption annuity } \\
\text { as a share of non oil GDP (4) }\end{array}$} \\
\hline & -13.1 & -8.9 & -6.5 & -1.0 & 0.4 & -1.1 & -2.3 & $\overline{-2.6}$ & -2.6 & -2.6 \\
\hline \multicolumn{11}{|l|}{ Sensitivity Tests } \\
\hline \multicolumn{11}{|l|}{ Oil Reference Price } \\
\hline $\begin{array}{l}\text { Higher Oil prices ( } 30 \text { percent higher } \\
\text { each year than baseline starting in 2009) }\end{array}$ & -13.8 & -9.7 & -7.4 & -1.7 & -0.4 & -2.9 & -4.1 & -4.4 & -4.5 & -4.5 \\
\hline $\begin{array}{l}\text { Lower Oil prices ( } 30 \text { percent lower } \\
\text { each year than baseline starting in 2009) }\end{array}$ & -12.4 & -8.0 & -5.7 & -0.2 & 1.2 & 0.9 & -0.2 & -0.5 & -0.6 & -0.6 \\
\hline \multicolumn{11}{|l|}{ Oil Production } \\
\hline $\begin{array}{l}\text { Higher Oil Production ( } 30 \text { percent higher } \\
\text { each year than baseline starting in 2009) }\end{array}$ & -13.7 & -9.6 & -7.2 & -1.6 & -0.2 & -2.5 & -3.7 & -4.0 & -4.1 & -4.1 \\
\hline $\begin{array}{l}\text { Lower Oil Produciton ( } 30 \text { percent lower } \\
\quad \text { each year than baseline starting in } 2009 \text { ) }\end{array}$ & -12.6 & -8.3 & -5.9 & -0.4 & 0.9 & 0.4 & -0.8 & -1.1 & -1.2 & -1.2 \\
\hline \multicolumn{11}{|l|}{ Tax Take } \\
\hline $\begin{array}{l}\text { Higher Tax Take (10 percent higher } \\
\text { each year than baseline starting 2014) }\end{array}$ & -13.2 & -9.0 & -6.6 & -1.0 & 0.3 & -1.2 & -2.4 & -2.7 & -2.8 & -2.7 \\
\hline $\begin{array}{l}\text { Lower Tax Take ( } 10 \text { percent lower } \\
\quad \text { each year than baseline starting } 2014)\end{array}$ & -13.1 & -8.9 & -6.5 & -0.9 & 0.4 & -0.9 & -2.1 & -2.4 & -2.5 & -2.5 \\
\hline \multicolumn{11}{|l|}{ Non oil Revenues } \\
\hline $\begin{array}{l}\text { Higher Non Oil Revenues ( } 10 \text { percent higher } \\
\text { each year than baseline starting 2009) }\end{array}$ & -13.7 & -9.6 & -7.1 & -1.0 & 0.5 & -1.1 & -2.2 & -2.5 & -2.6 & -2.6 \\
\hline $\begin{array}{l}\text { Higher Non Oil Revenues ( } 10 \text { percent lower } \\
\text { each year than baseline starting 2009) }\end{array}$ & -12.5 & -8.2 & -6.0 & -1.0 & 0.3 & -1.1 & -2.2 & -2.5 & -2.6 & -2.6 \\
\hline \multicolumn{11}{|l|}{ Real Interest Rate } \\
\hline Higher real interest rate $(=4.5$ percent $)$ & -13.3 & -9.1 & -6.7 & -1.2 & 0.2 & -1.5 & -2.6 & -3.0 & -3.0 & -3.0 \\
\hline Lower real interest rate ( $=3.5$ percent) & -13.0 & -8.7 & -6.4 & -0.8 & 0.5 & -0.7 & -1.8 & -2.2 & -2.2 & -2.2 \\
\hline \multicolumn{11}{|l|}{ Long run real Growth Rate } \\
\hline Higher long run real growth rate ( $=3.5$ percent) & -12.4 & -8.4 & -6.3 & -1.1 & 0.2 & -0.7 & -1.9 & -2.2 & -2.3 & -2.3 \\
\hline Lower long run real growth rate ( $=2.5$ percent) & -13.9 & -9.4 & -6.7 & -0.8 & 0.6 & -1.5 & -2.6 & -2.9 & -3.0 & -3.0 \\
\hline \multicolumn{11}{|l|}{ Habit persistence } \\
\hline Larger Habit parameter $(=0.7)$ & -14.5 & -9.7 & -6.8 & -0.9 & 0.5 & & & & & \\
\hline Smaller Habit parameter $(=0.5)$ & -12.1 & -8.6 & -6.4 & -1.0 & 0.3 & & & & & \\
\hline
\end{tabular}

Source: Fund Staff Estimates 
65. A permanent income framework that allows for gradual adjustment seems well suited to guide Chad's path towards a sustainable long term NOPD level. Given Chad's large investment and priority sector spending needs and large NOPD, fiscal frameworks guided by rules such as a constant government annuity as a share of GDP, a bird in hand approach or any other rule that essentially entails eliminating most of the NOPD in a short period of time (see Table 2 and Appendix Table 1), may be both infeasible and undesirable. Balanced budget rules are also problematic given that the large revenue fluctuations experienced by oil exporters would imply large expansions in spending when prices are high and large cuts when revenues decline, exacerbating fluctuations in aggregate demand. The recommended gradual $\mathrm{PIH}$ adjustment guidance should be complemented by ensuring that the adjustment path is consistent with short-term financing constraints.

66. Several important reforms are needed to achieve a considerable reduction in the NOPD. These include:

- $\quad$ Revenue administration reform and a review tax policy to strengthen the level of non-oil revenues. With respect to the revenue administration, this includes strengthening the operations of the large taxpayers unit, improving the selection criteria and quality of the audits, simplifying and automatizing customs procedures and ensuring that both the tax administration and customs have the material and human resources to carry out its functions appropriately. On tax policy, the review should focus on broadening the tax base including by reassessing the need for tax incentives and exemptions, and simplifying the tax structure to eliminate taxes with small collections that increase the administrative burden.

- Expenditure rationalization with a view to enhance the quality and poverty orientation of spending. Efforts in this area should be focused on implementing long standing reforms to rationalize the wage bill (biometric census of the civil service, computerization of the payroll, using the banking system to carry out payments, and demobilization of army personnel if the security situation permits), and reduce the cost of subsidies to loss making public enterprises through structural reforms (including introduction of an adequate billing system to improve collections and moving forward with ongoing initiatives to reduce fuel costs in STEE). A critical challenge is to improve the quality, cost and consistency with absorptive capacity of the investment budget. To this end, projects with sufficiently high rates of return should be selected through careful PRSP consistent prioritization, sufficient allocations should be provided for needed recurrent expenditures, non competitive procurement should be reduced, and ongoing projects should be completed before starting new ones.

- Public Financial Management reforms to improve budget control and mediumterm fiscal planning. This includes strict enforcement of budget procedures to avoid spending commitments without appropriations, issuance of clear regulations reducing 
the recourse to exceptional budget procedures, simplification and computerization of the spending chain to avoid undue delays in budget execution and procurement, introduction of an international standard budget classification to better track poverty reducing spending, strengthening the planning, budgeting and monitoring of execution of investment projects so that sufficient allocations are provided to ensure the finalization of ongoing multi-year investment projects, preparation of monthly treasury plans to improve cash management, and regular approval of budget review laws and publication of budget execution reports to enhance transparency and accountability. 


\section{Appendix II}

Appendix Table 1: Average Level of NOPD Under Additional PIH Approach Rules

\begin{tabular}{|c|c|c|c|c|c|}
\hline & 2009-2012 & 2013-2016 & $2017-2020$ & 2021-2045 & $2046-2070$ \\
\hline $\begin{array}{l}\text { PIH: Constant real government } \\
\text { consumption (infinite horizon) }\end{array}$ & -3.7 & -3.9 & -3.4 & -1.9 & -0.4 \\
\hline $\begin{array}{c}\text { PIH: Constant real per capita government } \\
\text { consumption (infinite horizon) }\end{array}$ & 0.0 & -1.0 & -1.1 & -1.0 & -0.7 \\
\hline $\begin{array}{l}\text { PIH: Constant real government } \\
\text { consumption (finite horizon) }\end{array}$ & -4.3 & -4.3 & -3.8 & -2.1 & -0.5 \\
\hline $\begin{array}{c}\text { PIH: Constant real per capita government } \\
\text { consumption (finite horizon) }\end{array}$ & -1.6 & -2.5 & -2.6 & -2.2 & -1.8 \\
\hline
\end{tabular}

Appendix Table 2: Sensitivity Analysis of NOPD Estimates for Additional PIH Approach Rules

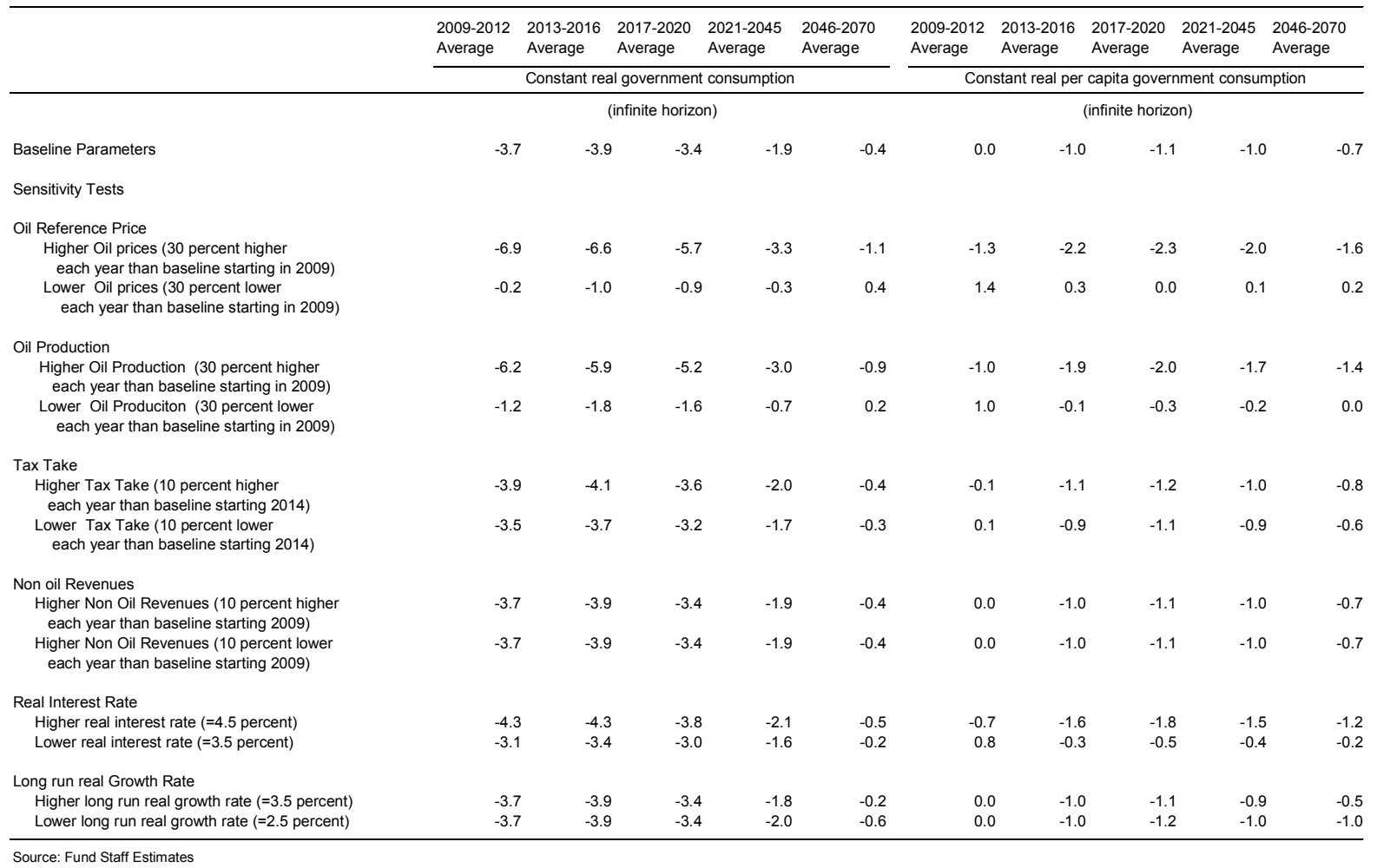


Appendix Table 2: Sensitivity Analysis of NOPD Estimates for Additional PIH Approach Rules (Concluded)

\begin{tabular}{|c|c|c|c|c|c|c|c|c|c|c|}
\hline & 2009-2012 & 2013-2016 & $2017-2020$ & 2021-2045 & 2046-2070 & 2009-2012 & 2013-2016 & $2017-2020$ & 2021-2045 & 2046-2070 \\
\hline & Average & Average & Average & Average & Average & Average & Average & Average & Average & Average \\
\hline & \multicolumn{5}{|c|}{ Constant real government consumption } & \multicolumn{5}{|c|}{ Constant real per capita government consumption } \\
\hline & \multicolumn{3}{|c|}{ (finite horizion) } & & & \multicolumn{5}{|c|}{ (finite horizon) } \\
\hline Baseline Parameters & -4.3 & -4.3 & -3.8 & -2.1 & -0.5 & -1.6 & -2.5 & -2.6 & -2.2 & -1.8 \\
\hline \multicolumn{11}{|l|}{ Sensitivity Tests } \\
\hline \multicolumn{11}{|l|}{ Oil Reference Price } \\
\hline $\begin{array}{l}\text { Higher Oil prices ( } 30 \text { percent higher } \\
\text { each year than baseline starting in 2009) }\end{array}$ & -7.8 & -7.3 & -6.3 & -3.7 & -1.2 & -3.8 & -4.5 & -4.4 & -3.9 & -3.2 \\
\hline $\begin{array}{l}\text { Lower Oil prices ( } 30 \text { percent lower } \\
\text { each year than baseline starting in 2009) }\end{array}$ & -0.5 & -1.2 & -1.1 & -0.4 & 0.3 & 0.7 & -0.4 & -0.6 & -0.5 & -0.3 \\
\hline \multicolumn{11}{|l|}{ Oil Production } \\
\hline $\begin{array}{l}\text { Higher Oil Production (30 percent higher } \\
\text { each year than baseline starting in 2009) }\end{array}$ & -7.0 & -6.6 & -5.7 & -3.3 & -1.1 & -3.3 & -4.0 & -4.0 & -3.5 & -2.9 \\
\hline $\begin{array}{l}\text { Lower Oil Produciton (30 percent lower } \\
\quad \text { each year than baseline starting in 2009) }\end{array}$ & -1.5 & -2.1 & -1.9 & -0.9 & 0.1 & 0.0 & -1.0 & -1.1 & -1.0 & -0.7 \\
\hline \multicolumn{11}{|l|}{ Tax Take } \\
\hline $\begin{array}{l}\text { Higher Tax Take ( } 10 \text { percent higher } \\
\text { each year than baseline starting 2014) }\end{array}$ & -4.5 & -4.6 & -4.0 & -2.2 & -0.5 & -1.8 & -2.6 & -2.7 & -2.3 & -1.9 \\
\hline $\begin{array}{l}\text { Lower Tax Take (10 percent lower } \\
\quad \text { each year than baseline starting 2014) }\end{array}$ & -4.0 & -4.1 & -3.6 & -2.0 & -0.4 & -1.5 & -2.3 & -2.4 & -2.1 & -1.7 \\
\hline \multicolumn{11}{|l|}{ Non oil Revenues } \\
\hline $\begin{array}{l}\text { Higher Non Oil Revenues ( } 10 \text { percent higher } \\
\text { each year than baseline starting 2009) }\end{array}$ & -4.3 & -4.3 & -3.8 & -2.1 & -0.5 & -1.6 & -2.5 & -2.6 & -2.2 & -1.8 \\
\hline $\begin{array}{l}\text { Higher Non Oil Revenues ( } 10 \text { percent lower } \\
\text { each year than baseline starting 2009) }\end{array}$ & -4.3 & -4.3 & -3.8 & -2.1 & -0.5 & -1.6 & -2.5 & -2.6 & -2.2 & -1.8 \\
\hline \multicolumn{11}{|l|}{ Real Interest Rate } \\
\hline Higher real interest rate $(=4.5$ percent $)$ & -4.7 & -4.7 & -4.1 & -2.3 & -0.6 & -2.1 & -2.9 & -2.9 & -2.5 & -2.1 \\
\hline Lower real interest rate $(=3.5$ percent $)$ & -3.8 & -4.0 & -3.5 & -1.9 & -0.4 & -1.2 & -2.1 & -2.2 & -1.9 & -1.5 \\
\hline \multicolumn{11}{|l|}{ Long run real Growth Rate } \\
\hline Higher long run real growth rate ( $=3.5$ percent) & -4.3 & -4.3 & -3.8 & -2.0 & -0.3 & -1.6 & -2.5 & -2.5 & -2.1 & -1.4 \\
\hline Lower long run real growth rate ( $=2.5$ percent) & -4.3 & -4.3 & -3.8 & -2.2 & -0.7 & -1.6 & -2.5 & -2.6 & -2.4 & -2.3 \\
\hline
\end{tabular}

The Carcillo et al (2007) government primary spending formula as a share of non-oil GDP $\left(\mathrm{g}_{\mathrm{t}}\right)$

$$
g_{t}=\left(1-\phi_{t}\right) \cdot \frac{r-\gamma}{R} \cdot\left(z_{t}+\sum_{j=1}^{N} \prod_{i=1}^{j} \frac{1+\gamma_{t+i}}{R_{t+i}} \cdot z_{t+j}+\tau_{t}+\sum_{j=1}^{\infty} \prod_{i=1}^{j} \frac{1+\gamma_{t+i}}{R_{t+i}} \cdot \tau_{t+j}-\frac{R_{t}}{1+\gamma_{t}} \cdot b_{t-1}\right)+\phi_{t} g_{t-1}
$$

where $\phi_{t}=\frac{\alpha\left(1+\gamma_{t}\right)}{R_{t}}, \alpha$ is the habit persistence parameter, $\gamma_{\mathrm{t}+\mathrm{i}}$ is the real growth rate of non oil GDP in year $t+i, R_{t+i}$ is one plus the real interest rate in year $t+i, \gamma$ is the long term real growth rate of non oil GDP, $z_{t+j}$ is the level of oil revenue as a share of non oil GDP for year $t+j, \tau_{t+j}$ is the level of non oil revenues for year $t+j$ and $b_{t-}$ ${ }_{1}$ is the level of debt as a share of non oil GDP in the previous period for $i=1, \ldots j$ and $j=1, \ldots$. , infinity.

This equation shows that, with habit formation, the government primary spending is a linear combination of the government primary spending level in the previous period and the permanent income level as indicated in the text. The implication is that if the previous period's NOPD is higher than the permanently sustainable level, then the NOPD is expected to adjust to the permanently sustainable level over a number of periods. In contrast, without habits $(\alpha=0)$, the policy would be to adjust the NOPD abruptly to the permanently sustainable level in a single period. 


\section{References}

Ballasone, Fabrizio, Takizawa, Hajime and Zebregs, Harm, 2006 "Managing Russia's Oil Wealth: An Assessment of Sustainable Expenditure Paths," IMF Country Report No. 06/325, pp 3-43.

Baunsgaard, Thomas, 2003, "Fiscal Policy in Nigeria: Any Role for Rules?,” IMF Working Paper No. 03/155 (Washington: International Monetary Fund).

Barnett, Steven. and Ossowski, Rolando., 2003 "Operational Aspects of Fiscal Policy in Oil Producing Countries" in Davis, J., R. Ossowski, and A. Fedelino, 2003, Fiscal Policy Formulation and Implementation in Oil-Producing Countries (Washington: International Monetary Fund).

Basdevant, Olivier, 2006 "Are Diamonds Forever? Using a Lifecycle Approach to Analyze Botswana's Reliance on Diamond Revenues," IMF Country Report No. 06/228, pp 4-19.

Clausen, Jens, 2007, "Calculating Fiscal Sustainability Benchmarks for Botswana" IMF Country Report No. 07/375, pp 2-11.

Carcillo, Stephane, Leigh, Daniel and Villafuerte, Mauricio, 2007, "Catch-Up Growth, Habits, Oil Depletion, and Fiscal Policy: Lessons from the Republic of Congo," IMF Working Paper No. 07/80 (Washington: International Monetary Fund).

Gylfanson, Thorvaldur,2001 "Lessons from the Dutch Disease:Causes, Treatment, and Cures," Institute of Economic Studies, Working Paper Series.

de Carvalho Filho, Irineu 2006, "Managing Oil Wealth" IMF Country Report No. 06/340, pp. $2-14$

Katz, M., U. Bartsch, H. Malothra, and M. Cue, 2004, "Lifting the Oil Curse-Improving Petroleum Revenue Management in Sub-Saharan Africa," (Washington: International Monetary Fund).

Leigh, Daniel, and Jan-Peter Olters, 2006, "Natural-Resource Depletion, Habit Formation, and Sustainable Fiscal Policy: Lessons from Gabon," IMF Working Paper No. 06/193 (Washington: International Monetary Fund).

Sala-i-Martin, Xavier, and Arvind Subramanian, 2003, "Addressing the Natural Resource Curse: An Illustration from Nigeria” IMF Working Paper No. 03/139 (Washington: International Monetary Fund). 
Segura, Alonso, 2006, "Management of Oil Wealth Under the Permanent Income Hypothesis: The Case of São Tomé and Príncipe," IMF Working Paper No. 06/183 (Washington: International Monetary Fund).

Takizawa, Hajime, and others, 2004, “Are Developing Countries Better Off Spending Their Oil Wealth Upfront?,” IMF Working Paper No. 04/14 (Washington: International Monetary Fund).

Ossowski, Rolando., and others, 2008, Managing the Oil Revenue Boom: The Role of Fiscal Institutions, IMF Occasional Paper No. 260 (Washington: International Monetary Fund). 